Article

\title{
Chromone Derivatives and Other Constituents from Cultures of the Marine Sponge-Associated Fungus Penicillium erubescens KUFA0220 and Their Antibacterial Activity
}

Decha Kumla 1,2 (D), José A. Pereira 1,2 (D), Tida Dethoup ${ }^{3}$, Luis Gales ${ }^{1,4}$ (i), Joana Freitas-Silva ${ }^{1,2}$, Paulo M. Costa ${ }^{1,2}$ (D), Michael Lee ${ }^{5}$, Artur M. S. Silva ${ }^{6}$ (i), Nazim Sekeroglu ${ }^{7}$,

Madalena M. M. Pinto 2,8,* (i) and Anake Kijjoa 1,2,* (iD

1 ICBAS-Instituto de Ciências Biomédicas Abel Salazar, Universidade do Porto, Rua de Jorge Viterbo Ferreira, 228, 4050-313 Porto, Portugal; Decha1987@hotmail.com (D.K.); jpereira@icbas.up.pt (J.A.P.); lgales@ibmc.up.pt (L.G.); joanafreitasdasilva@gmail.com (J.F.-S.); pmcosta@icbas.up.pt (P.M.C.)

2 Interdisciplinary Centre of Marine and Environmental Research (CIIMAR), Universidade do Porto, Terminal de Cruzeiros do Porto de Lexões, Av. General Norton de Matos s/n, 4450-208 Matosinhos, Portugal

3 Department of Plant Pathology, Faculty of Agriculture, Kasetsart University, Bangkok 10240, Thailand; tdethoup@yahoo.com

4 Instituto de Biologia Molecular e Celular (i3S-IBMC), Universidade do Porto, Rua de Jorge Viterbo Ferreira, 228, 4050-313 Porto, Portugal

5 Department of Chemistry, University of Leicester, University Road, Leicester LE 7 RH, UK; ml34@leicester.ac.uk

6 Departamento de Química \& QOPNA, Universidade de Aveiro, 3810-193 Aveiro, Portugal; artur.silva@ua.pt

7 Department of Food Engineering, Faculty of Engineering and Architecture, Kilis 7 Aralık University, 79000 Kilis, Turkey; nsekeroglu@gmail.com

8 Laboratório de Química Orgânica, Departamento de Ciências Químicas, Faculdade de Farmácia, Universidade do Porto, Rua de Jorge Viterbo Ferreira, 228, 4050-313 Porto, Portugal

* Correspondence: madalena@ff.up.pt (M.M.M.P.); ankijjoa@icbas.up.pt (A.K.); Tel.: +351-22-042-8331 (M.M.M.P. \& A.K.); Fax: +351-22-206-2232 (M.M.M.P. \& A.K.)

Received: 2 August 2018; Accepted: 18 August 2018; Published: 20 August 2018 updates

\begin{abstract}
A previously unreported chromene derivative, 1-hydroxy-12-methoxycitromycin (1c), and four previously undescribed chromone derivatives, including pyanochromone (3b), spirofuranochromone (4), 7-hydroxy-6-methoxy-4-oxo-3-[(1E)-3-oxobut-1-en-1-yl]-4H-chromene-5carboxylic acid (5), a pyranochromone dimer (6) were isolated, together with thirteen known compounds: $\beta$-sitostenone, ergosterol 5,8-endoperoxide, citromycin (1a), 12-methoxycitromycin (1b), myxotrichin D (1d), 12-methoxycitromycetin (1e), anhydrofulvic acid (2a), myxotrichin C (2b), penialidin D (2c), penialidin F (3a), SPF-3059-30 (7), GKK1032B (8) and secalonic acid A (9), from cultures of the marine sponge- associated fungus Penicillium erubescens KUFA0220. Compounds 1a-e, 2a, 3a, 4, 7-9, were tested for their antibacterial activity against Gram-positive and Gram-negative reference and multidrug-resistant strains isolated from the environment. Only 8 exhibited an in vitro growth inhibition of all Gram-positive bacteria whereas 9 showed growth inhibition of methicillin-resistant Staphyllococus aureus (MRSA). None of the compounds were active against Gram-negative bacteria tested.
\end{abstract}

Keywords: Penicillium erubescens; Aspergillaceae; marine sponge-associated fungus; Neopetrosia sp.; chromone derivatives; GKK 1032B; pyranochromone; spirofuranochromone; antibacterial activity 


\section{Introduction}

The fungi of the genus Penicillium (Family Aspergillaceae) are the most common fungi occurring in a diverse range of habitats from soil to vegetation to various food products, air, indoor environments, and marine environments. They have a worldwide distribution and a large economic impact on human life [1]. The marine-derived Penicillium species can be found to be associated with a variety of marine invertebrates such as marine sponges, corals, and tunicates, as well as with fish, marine algae, mangroves and also from the sediments; although sediments and sponges are their main sources or hosts for producing new marine natural products. Interestingly, marine-derived Penicillium species produce diverse structural classes of secondary metabolites such as polyketides, sterols, terpenoids, alkaloids, among others, and more than half of these metabolites exhibited bioactivities [2].

Thus, in our ongoing search for antibiotics from marine-derived fungi from the tropical sea, we investigated secondary metabolites from cultures of Penicillium erubescens KUFA 0220, which was isolated from the marine sponge Neopetrosia sp., collected from the coral reef at Samaesan Island, Chonburi province, in the Gulf of Thailand.

Chromatographic fractionation and the further purification of the crude ethyl acetate extract of the cultures of P. erubescens KUFA 0220, furnished an unreported chromene derivative, 1-hydroxy12-methoxycitromycin (1c), and four previously undescribed chromone derivatives, including a pyanochromone (3b), a spirofuranochromone (4), 7-hydroxy-6-methoxy-4-oxo-3-[(1E)-3-oxobut-1en-1-yl]-4H-chromene-5-carboxylic acid (5), and a pyranochromone dimer (6) (Figure 1), in addition to thirteen known compounds: $\beta$-sitostenone [3,4], citromycin (1a) [5], 12-methoxycitromycin (1b) [5], myxotrichin D (1d) [6], 12-methoxycitromycetin (1e) [5], anhydrofulvic acid (2a) [7,8], myxotrichin C (2b) [6], penialidin D (2c) [9], penialidin F (3a) [9,10], SPF-3059-30 (7) [11], GKK1032B (8) [12-14] and secalonic acid A (9) [3] (Figure 1). The structures of the previously undescribed compounds were established based on extensive analyses of their 1D and 2D NMR as well as HRMS data while the identity of the known compounds was elucidated by comparison of their ${ }^{1} \mathrm{H}$ and ${ }^{13} \mathrm{C}$ NMR data with those reported in the literature. The absolute configuration of the stereogenic carbon of the previously unreported $\mathbf{4}$ was established by an X-ray analysis whereas those of the previously undescribed $\mathbf{6}$ and penialidin F (3a) were determined by comparison of their calculated and experimental ECD spectra.

Compounds 1a-e, 2a, 3a, 4, 7-9 were tested for their antibacterial activity against five reference bacterial strains consisting of three Gram-positive (Staphylococcus aureus ATCC 29213, Enterococcus faecium ATCC 19434 and Enterococcus faecalis ATCC 29212) and two Gram-negative bacteria (Escherichia coli ATCC 25922 and Pseudomonas aeruginosa ATCC 27853), three multidrug-resistant isolates from the environment (MRSA S. aureus 66/1, VRE E. faecium 1/6/63 and E. faecalis B3/101) and a clinical isolate ESBL E. coli SA/2. Some of the isolated compounds were also investigated for their capacity to inhibit biofilm formation in the four reference strains as well as for their potential synergism with the clinically used antibiotics against multidrug-resistant isolates from the environment. 
<smiles>[R]c1cc(=O)c2c(o1)-c1c(cc(O)c([R])c1[R])OC2</smiles>

1a: $R_{1}=O H, R_{2}=H, R_{3}=M e$ b: $\mathrm{R}_{1}=\mathrm{OMe}, \mathrm{R}_{2}=\mathrm{H}, \mathrm{R}_{\mathbf{3}}=\mathrm{Me}$ c: $\mathbf{R}_{\mathbf{1}}=\mathrm{OMe}, \mathrm{R}_{\mathbf{2}}=\mathrm{H}, \mathrm{R}_{3}=\mathrm{CH}_{\mathbf{2}} \mathrm{OH}$ d: $R_{1}=H, R_{2}=\mathrm{COOH}, R_{3}=\mathrm{Me}$ e: $R_{1}=\mathrm{OMe}, \mathbf{R}_{2}=\mathrm{COOH}, \mathrm{R}_{3}=\mathrm{Me}$<smiles>[R]c1c(O)c([R])c2c(=O)c3c(oc2c1[R3])C=C(C)OC3</smiles>

$$
\begin{aligned}
\text { 2a: } R_{1} & =\mathrm{COOH}, \mathrm{R}_{2}=\mathrm{OH}, \mathrm{R}_{3}=\mathrm{H} \\
\text { b: } \mathrm{R}_{1} & =\mathrm{H}, \mathrm{R}_{2}=\mathrm{OH}, \mathrm{R}_{3}=\mathrm{H} \\
\text { c: } \mathrm{R}_{1} & =\mathrm{H}, \mathrm{R}_{2}=\mathrm{OMe}, \mathrm{R}_{3}=\mathrm{COOH}
\end{aligned}
$$<smiles>CC1(C)Cc2oc3cc(O)c(O)cc3c(=O)c2CO1</smiles>

$3 b$<smiles>CC1=CC(=O)C2(COc3cc(O)c(O)cc32)C1=O</smiles>

4<smiles>C[C@@]1(O)Cc2oc3cc(O)c(O)cc3c(=O)c2CO1</smiles>

3a<smiles>COc1c(O)cc2occ(/C=C/C(C)=O)c(=O)c2c1C(=O)O</smiles>

5

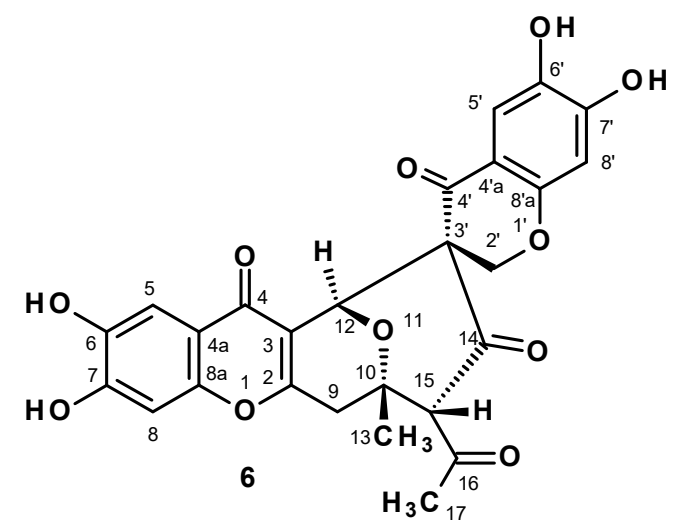<smiles>CC(=O)c1c(C)c(C(O)=C2COc3cc(O)c(O)cc3C2=O)cc2c(=O)c3cc(O)c(O)cc3oc12</smiles>

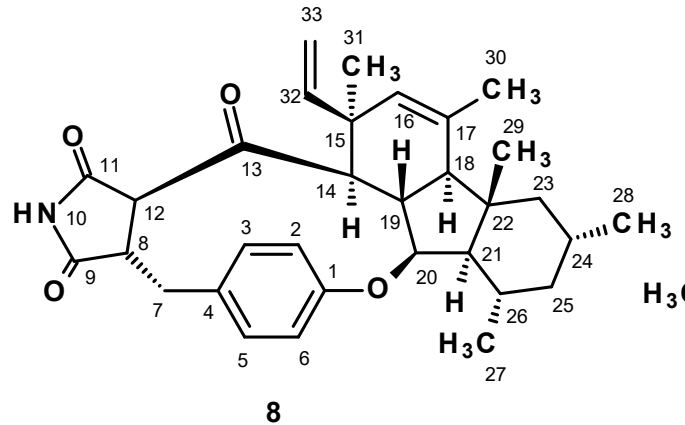<smiles>COC(=O)[C@]12OC(=C(O)C[C@@H](C)[C@@H]1O)C(=O)c1cc(-c3ccc4c(c3O)C(=O)C3=C(O)C[C@@H](C)[C@@H](O)[C@]3(C(=O)OC)O4)ccc12</smiles>

Figure 1. The structures of some secondary metabolites, isolated from cultures of the marine sponge-associated fungus P. erubescens KUFA 0220.

\section{Results and Discussion}

The structure of $\beta$-sitostenone [3], ergosterol 5,8-endoperoxide [4] (Figure S1), citromycin (1a) [5], 12-methoxycitromycin (1b) [5], myxotrichin D (1d) [6], 12-methoxycitromycetin (1e) [5], anhydrofulvic acid (2a) [7,8], myxotrichin C (2b) [6], penialidin D (2c) [9], penialidin F (3a) [9,10], SPF-3059-30 (7) [11], GKK1032B (8) [12-14], and secalonic acid A (9) [3,15] (Figure 1) were elucidated by analysis of their 1D and 2D NMR spectra as well as HRMS data, and also by comparison of their spectral data (Figures S2-S11, S15-S29, S45-S50, S52 and S53) to those reported in the literature. In the case of 
GKK1032B (8), the X-ray analysis was also performed to confirm the absolute configurations of all the stereogenic centers (Figure S51).

Compound 1c was isolated as a white solid ( $\left.\mathrm{mp} 232-233^{\circ} \mathrm{C}\right)$, and its molecular formula $\mathrm{C}_{14} \mathrm{H}_{12} \mathrm{O}_{6}$ was established based on its (+)-HRESIMS $m / z 277.0715[\mathrm{M}+\mathrm{H}]^{+}$, (calculated 277.0712 for $\mathrm{C}_{14} \mathrm{H}_{13} \mathrm{O}_{6}$ ), indicating nine degrees of unsaturation. The IR spectrum showed absorption bands for the hydroxyl $\left(3420 \mathrm{~cm}^{-1}\right)$, conjugated ketone carbonyl $\left(1662 \mathrm{~cm}^{-1}\right)$, aromatic $\left(1627,1555 \mathrm{~cm}^{-1}\right)$, and ether $\left(1270 \mathrm{~cm}^{-1}\right)$ groups. The ${ }^{13} \mathrm{C}$ NMR spectrum of 1c (Table 1, Figure S11) displayed fourteen carbon signals which, according to DEPTs and HSQC spectra (Table 1, Figure S12), can be classified as one conjugated ketone carbonyl $\left(\delta_{C} 174.8\right)$, seven quaternary $\operatorname{sp}^{2}\left(\delta_{C} 167.3,155.2,152.2,151.9\right.$, $143.6,111.2,105.9)$, three methine $\mathrm{sp}^{2}\left(\delta_{C} 110.7,106.5,104.1\right)$, two oxymethylene $\mathrm{sp}^{3}\left(\delta_{C} 62.5\right.$ and 59.5), and one methoxyl $\left(\delta_{C} 56.4\right)$ carbon. The ${ }^{1} \mathrm{H}$ NMR spectrum (Table 1, Figure S10) showed two aromatic singlets at $\delta_{\mathrm{H}} 7.15$ and 6.44 , another singlet of one olefinic proton at $\delta_{\mathrm{H}} 6.25$, two singlets of oxymethylene protons at $\delta_{\mathrm{H}} 5.02(2 \mathrm{H})$ and $4.41(2 \mathrm{H})$, and a singlet of methoxyl protons at $\delta_{\mathrm{H}} 3.80(3 \mathrm{H})$. The general features of the ${ }^{1} \mathrm{H}$ and ${ }^{13} \mathrm{C}$ NMR spectra of $1 \mathrm{c}$ resembled those of 12-methoxycitromycin (1b), which was previously isolated from the Australian marine-derived and terrestrial Penicillium spp. [5], and also isolated in this work. The only difference between the two compounds is the methyl group in $1 \mathbf{b}\left(\delta_{\mathrm{H}} 2.34, \mathrm{~d}, J=0.6 \mathrm{~Hz} ; \delta_{\mathrm{C}} 19.2\right)$ is replaced by a hydroxymethyl group $\left(\delta_{\mathrm{H}} 4.41 ; \delta_{\mathrm{C}} 59.5\right)$ in 1c. The position of the methoxyl group was also confirmed by the NOESY correlation from the methoxyl protons to $\mathrm{H}-13\left(\delta_{\mathrm{H}} 7.15\right.$, s) (Figure S14). Therefore, 1c is 1-hydroxy-12-methoxycitromycin. The literature search revealed that $1 \mathrm{c}$ has never been previously reported.

Table 1. The ${ }^{1} \mathrm{H}$ and ${ }^{13} \mathrm{C}$ NMR (DMSO- $d_{6}, 500.13$ and $125.4 \mathrm{MHz}$ ) and HMBC assignment for 1c.

\begin{tabular}{cccc}
\hline Position & $\delta_{\mathrm{C}}$, Type & $\delta_{\mathrm{H}},(J$ in Hz) & HMBC \\
\hline 1 & $59.5, \mathrm{CH}_{2}$ & $4.41, \mathrm{brs}$ & $\mathrm{C}-2,5$ \\
2 & $167.3, \mathrm{C}$ & - & - \\
3 & $104.1, \mathrm{CH}$ & $6.25, \mathrm{~s}$ & $\mathrm{C}-1,2,5$ \\
4 & $174.8, \mathrm{CO}$ & - & - \\
5 & $111.2, \mathrm{C}$ & - & - \\
6 & $62.6, \mathrm{CH}_{2}$ & $5.02, \mathrm{~s}$ & $\mathrm{C}-4,5,7,9$ \\
7 & $155.2, \mathrm{C}$ & - & - \\
8 & $105.9, \mathrm{C}$ & - & - \\
9 & $152.2, \mathrm{C}$ & & - \\
10 & $106.5, \mathrm{CH}$ & $6.44, \mathrm{~s}$ & $\mathrm{C}-7,8,9,11,12$ \\
11 & $151.9, \mathrm{C}$ & - & - \\
12 & $143.6, \mathrm{C}$ & - & - \\
13 & $110.7, \mathrm{CH}$ & $7.15, \mathrm{~s}$ & $\mathrm{C}-7,8,9,11,12$ \\
$\mathrm{OCH}_{3}-12$ & $56.4, \mathrm{CH} 3$ & 3.80 & $\mathrm{C}-12$ \\
\hline
\end{tabular}

The analysis of the ${ }^{1} \mathrm{H},{ }^{13} \mathrm{C}$ NMR (Table 2, Figures S28 and S29) and the (+)-HRESIMS spectra of 3a revealed that its planar structure was the same as that of penialidin F, previously isolated from the culture of Penicillium janthinellum DT-F29, collected from marine sediments [9]. Curiously, even though the authors reported the optical rotation of penialidin $\mathrm{F}$ as levorotatory $\left([\alpha]_{\mathrm{D}}^{25}-4.13, c=1.0, \mathrm{MeOH}\right)$, they did not determine the absolute configuration of its stereogenic carbon (C-2). Similarly, we have also found the optical rotation of the 3a levorotatory, $\left([\alpha]_{\mathrm{D}}^{25}-7.5, c=0.04, \mathrm{MeOH}\right)$. Since $3 a$ was not isolated as a suitable crystal for X-ray analysis, its calculated ECD spectrum was performed to compare with the experimental ECD spectrum. Therefore, the conformational analysis of $3 \mathbf{a}$ by molecular mechanics (MM2 and MMFF95 force fields) focused on combinations of hydroxyl $120^{\circ}$ rotations and two 3,6-dihydro- $2 \mathrm{H}$-pyran-2-ol ring conformations. A total of 30 conformations were energetically minimized and ranked using a faster DFT model (smaller basis set, APFD/6-31G). The lowest three of these, representing $99 \%$ of the model Boltzmann population, were then further energetically minimized with a larger basis set (APFD/6-311+G(2d,p)). The most stable conformation is depicted in Figure 2 and represents $64 \%$ of the Boltzmann population while the other two amount to $25 \%$ and $11 \%$. 
Table 2. The ${ }^{1} \mathrm{H}$ and ${ }^{13} \mathrm{C}$ NMR of $3 \mathbf{a}\left(\mathrm{DMSO}_{6}, 300.13\right.$ and $75.4 \mathrm{MHz}$ ) and $3 \mathbf{b}$ (DMSO, 500.13 and $125.4 \mathrm{MHz}$ ).

\begin{tabular}{|c|c|c|c|c|}
\hline \multicolumn{3}{|c|}{$3 a$} & \multicolumn{2}{|c|}{$3 b$} \\
\hline Position & $\delta_{C}$, Type & $\delta_{\mathrm{H}},(J$ in $\mathrm{Hz})$ & $\delta_{C}$, Type & $\delta_{\mathrm{H}},(J$ in $\mathrm{Hz})$ \\
\hline 1 & $28.4, \mathrm{CH}_{3}$ & $1.45, \mathrm{~s}$ & $22.4, \mathrm{CH}_{3}$ & $1.44, \mathrm{~s}$ \\
\hline 2 & $94.2, \mathrm{C}$ & - & $97.7, \mathrm{C}$ & - \\
\hline 3 & $37.5, \mathrm{CH}_{2}$ & $2.55, \mathrm{~d}(17.5)$ & $37.1, \mathrm{CH}_{2}$ & $2.63, \mathrm{dd}(17.6,2.6)$ \\
\hline & 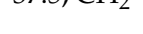 & 2.87, d (17.5) & & 2.96, dd $(17.6,2.6)$ \\
\hline 4 & 158.7, C & - & 157.9, C & - \\
\hline 5 & 113.5, C & - & $113.0, \mathrm{C}$ & - \\
\hline 6 & $56.3, \mathrm{CH}_{2}$ & $4.45, \mathrm{~s}$ & $52.7, \mathrm{CH}_{2}$ & 4.22, dt $(14.9,0.9)$ \\
\hline 7 & $173.4 \mathrm{CO}$ & - & $1732 \mathrm{CO}$ & $4.52, \mathrm{dd}(14.9,2.1)$ \\
\hline 8 & $115.4, \mathrm{C}$ & - & $115.4, \mathrm{C}$ & $\begin{array}{c}- \\
-\end{array}$ \\
\hline 9 & 152.1, C & - & $152.1, \mathrm{C}$ & - \\
\hline 10 & 102.7, CH & $6.83, \mathrm{~s}$ & 102.7, CH & $6.83, \mathrm{~s}$ \\
\hline 11 & $150.8, \mathrm{C}$ & - & $150.8, \mathrm{C}$ & - \\
\hline 12 & 144.3, C & - & $144.4, \mathrm{C}$ & - \\
\hline 13 & 107.4, CH & $7.26, \mathrm{~s}$ & 107.4, CH & $7.26, \mathrm{~s}$ \\
\hline $\mathrm{OCH}_{3}$ & - & - & $48.3, \mathrm{CH}_{3}$ & $3.21, \mathrm{~s}$ \\
\hline
\end{tabular}

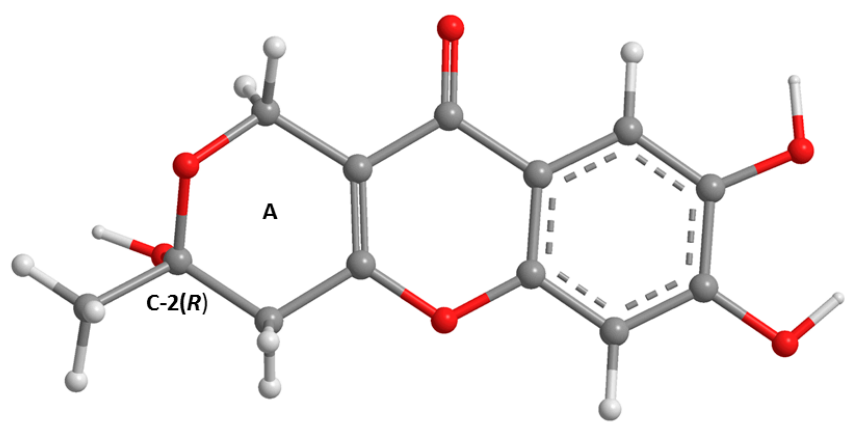

Figure 2. The most stable APFD/6-311+G(2d,p) conformation of $\mathbf{3 a}(\mathrm{C}-2 R)$. The asymmetric carbon is presented with the hydroxyl group facing straight down.

These three models were then used to calculate the expected Boltzmann-averaged ECD spectrum of 3a's $R$ enantiomer. The good fit between the calculated and experimental ECD spectra shown in Figure 3 is enough evidence to conclude that $\mathbf{3 a}$ is the $R$ enantiomer. However, the weak experimental ECD signal of 3a could indicate that this compound does not exist as a pure $R$ enantiomer but as an enantiomeric mixture with an excess of the $R$ enantiomer.

Compound $\mathbf{3} \mathbf{b}$ was isolated as a 1:2 mixture (estimated from the integration of the proton signals in the ${ }^{1} \mathrm{H}$ NMR spectrum) with myxotrichin C (2b). Based on the (+)-HRESIMS $m / z 279.0878[\mathrm{M}+\mathrm{H}]^{+}$, (calculated 277.0869 for $\mathrm{C}_{14} \mathrm{H}_{15} \mathrm{O}_{6}$ ), the molecular formula $\mathrm{C}_{14} \mathrm{H}_{14} \mathrm{O}_{6}$ was attributed to $3 \mathbf{b}$. The ${ }^{1} \mathrm{H}$ and ${ }^{13} \mathrm{C}$ NMR spectra of $\mathbf{3 b}$ (a minor compound) resembled those of penialidin $\mathrm{F}$ (3a) (Table 2). The ${ }^{13} \mathrm{C}$ NMR spectrum of $\mathbf{3} \mathbf{b}$ (Table 2, Figure S22) exhibited fourteen carbon signals which, in combination with DEPTs and HSQC spectra (Figure S24), can be categorized as one conjugated ketone carbonyl $\left(\delta_{C} 173.2\right)$, six quaternary $\mathrm{sp}^{2}\left(\delta_{C} 157.9,152.1,150.8,144.4,115.4,113.0\right)$, two methine $\mathrm{sp}^{2}\left(\delta_{C} 107.4\right.$ and 102.7), one ketal $\left(\delta_{C} 97.7\right)$, one oxymethylene $\mathrm{sp}^{3}\left(\delta_{C} 57.1\right)$, one methylene $\mathrm{sp}^{3}\left(\delta_{C} 37.1\right)$, one methyl $\left(\delta_{C} 22.4\right)$, and one methoxyl $\left(\delta_{C} 48.3\right)$ carbon. The ${ }^{1} \mathrm{H}$ NMR spectrum (Figure S21) displayed two aromatic singlets at $\delta_{\mathrm{H}} 7.26(\mathrm{H}-13)$ and $6.83(\mathrm{H}-10)$, two pairs of geminally coupled methylene protons at $\delta_{\mathrm{H}} 4.52, \mathrm{dd}(J=14.9,0.9 \mathrm{~Hz}) / 4.22, \mathrm{dt},(J=4.9,2.1 \mathrm{~Hz})$ and 2.63, $\mathrm{dd}(J=17.6,1.5 \mathrm{~Hz}) / 2.96, \mathrm{dd}(J=1.76$, $2.6 \mathrm{~Hz}$ ), a methyl singlet at $\delta_{\mathrm{H}} 1.44$ and a methoxyl singlet at $\delta_{\mathrm{H}} 3.21$. Comparison of the ${ }^{1} \mathrm{H}$ and ${ }^{13} \mathbf{C}$ data of $\mathbf{3} \mathbf{b}$ with those of $\mathbf{3 a}$ (Table 2) led to the conclusion that $\mathbf{3} \mathbf{b}$ is a methyl ketal of $\mathbf{3 a}$. This hypothesis is confirmed not only by the molecular formula of $\mathbf{3 b}$, which is $14 \mathrm{amu}$ more than that of 3a, but also by the HMBC correlation (Figure S25) of the singlet of the methoxyl protons to the ketal carbon at $\delta_{C}$ 97.7. Therefore, $\mathbf{3 b}$ was named penialidin $G$. 


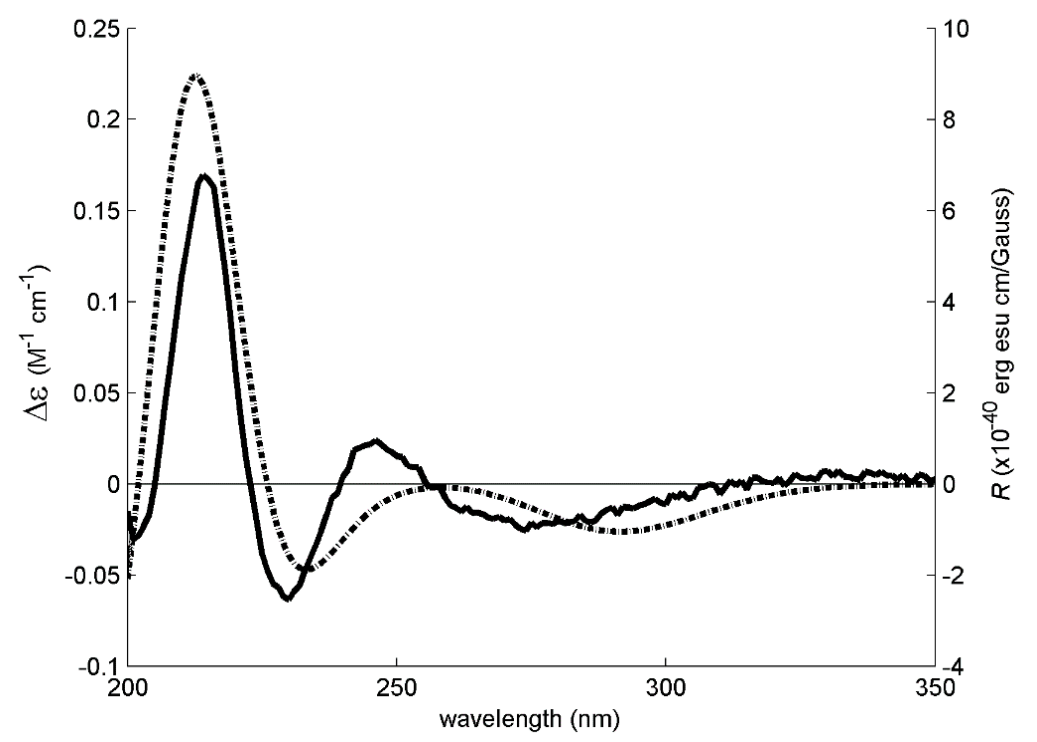

Figure 3. The experimental (solid line, left axis) and simulated (dotted line, right axis) ECD spectra of $3 a / C-2(R)$. The ECD experimental signal was very weak, requiring the use of 40 accumulations, increased digital integration time and post-acquisition noise filtering (moving mean).

Surprisingly, the ECD spectrum of the mixture of myxotrichin $C(\mathbf{2} \mathbf{b})$ and $\mathbf{3 b}$ did not exhibit any Cotton effects. Consequently, we concluded that $\mathbf{3 b}$ is a mixture of both enantiomers.

The biogenesis of $\mathbf{2} \mathbf{b}, \mathbf{3} \mathbf{a}$, and $\mathbf{3} \mathbf{b}$ can be hypothesized as originated from the hexaketide intermediate (i) (Figure 4). Enzyme-catalyzed nucleophilic addition of the primary hydroxyl group to the ketone carbonyl led to a cyclization to form a 2-methyl-3,6-dihydro-2H-pyran-2-ol ring, through an intermediate (ii), in 3a (2R). Dehydration of the hemiketal in 3a furnished myxotrichin C (2b), which underwent a nucleophilic addition of methanol (chromatographic solvent) at C-2 to form an enantiomeric mixture of $\mathbf{3} \mathbf{b}$. Therefore, $\mathbf{3} \mathbf{b}$ can be an artifact and not a natural product. The co-occurrence of $\mathbf{2} \mathbf{b}$ and $\mathbf{3} \mathbf{b}$ can be a concrete proof of this hypothesis.

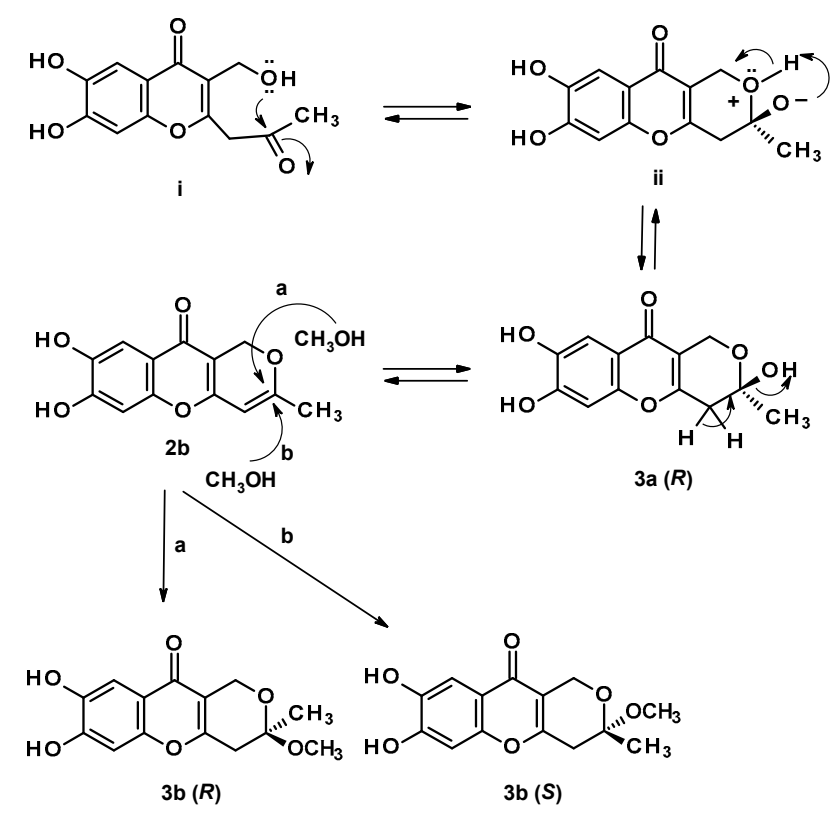

Figure 4. The formation of $\mathbf{3 a}, \mathbf{2} \mathbf{b}$ and a pair of enantiomers of $\mathbf{3 b}$ by nucleophilic addition of methanol to $\mathbf{2 b}$. 
Compound 4 was isolated as white crystals ( $\mathrm{mp} 150-152{ }^{\circ} \mathrm{C}$ ), and its molecular formula was established as $\mathrm{C}_{13} \mathrm{H}_{10} \mathrm{O}_{6}$ on the basis of its (+)-HRESIMS $m / z 263.0569[\mathrm{M}+\mathrm{H}]^{+}$, (calculated 263.0556 for $\mathrm{C}_{13} \mathrm{H}_{11} \mathrm{O}_{6}$ ), indicating nine degrees of unsaturation. The IR spectrum showed absorption bands for hydroxyl $\left(3491,3376 \mathrm{~cm}^{-1}\right)$, conjugated ketone carbonyls $\left(1679,1661 \mathrm{~cm}^{-1}\right)$, olefin $\left(1648 \mathrm{~cm}^{-1}\right)$, aromatic $\left(1587,1523 \mathrm{~cm}^{-1}\right)$, and ether $\left(1276 \mathrm{~cm}^{-1}\right)$ groups. The ${ }^{13} \mathrm{C}$ NMR spectrum (Table 3, Figure S31) displayed thirteen carbon signals which were categorized, according to the DEPTs and HSQC spectra (Figure S33), as two conjugated ketone carbonyls $\left(\delta_{C} 198.3\right.$ and 181.6), four oxyquaternary sp ${ }^{2}\left(\delta_{C} 191.4\right.$, $156.9,155.9,141.9)$, one quaternary $\mathrm{sp}^{2}\left(\delta_{C} 111.1\right)$, three methine $\mathrm{sp}^{2}\left(\delta_{C} 110.3,103.8,103.2\right)$, one quaternary sp ${ }^{3}\left(\delta_{C} 86.3\right)$, one oxymethylene $\operatorname{sp}^{3}\left(\delta_{C} 69.8\right)$ and one methyl $\left(\delta_{C} 16.4\right)$ carbons. The ${ }^{1} \mathrm{H}$ NMR spectrum (Table 3, Figure S31) showed two aromatic singlets at $\delta_{\mathrm{H}} 7.05$ and 6.41 , a doublet of an olefinic proton at $\delta_{\mathrm{H}} 5.68(\mathrm{~J}=0.6 \mathrm{~Hz})$, a pair of doublets of the oxymethylene protons at $\delta_{\mathrm{H}} 4.49$ $(J=12.4 \mathrm{~Hz}) / 4.63(J=12.4 \mathrm{~Hz})$, and a methyl singlet at $\delta_{\mathrm{H}} 2.31$, in addition to a broad signal of the hydroxyl protons at $\delta_{\mathrm{H}} 10.01$. The presence of the 6,7-dihydroxy-2,3-dihydro-4H-1-benzopyran-4-one moiety was corroborated by the HMBC correlations (Table 3, Figure S34) from $\mathrm{H}-5\left(\delta_{\mathrm{H}} 7.05, \mathrm{~s}\right)$ to C-4 $\left(\delta_{C} 181.6\right), C-6\left(\delta_{C} 141.9\right), C-7\left(\delta_{C} 155.9\right)$ and C-8a $\left(\delta_{C} 156.9\right) ; H-8\left(\delta_{H} 6.41, s\right)$ to C-4, C-4a $\left(\delta_{C} 111.1\right), C-6$, C-7 and C-8a, and from $\mathrm{H}_{2}-2\left(\delta_{\mathrm{H}} 4.49, \mathrm{~d}, J=12.4 \mathrm{~Hz} / 4.63, \mathrm{~d}, 12.4 \mathrm{~Hz}\right)$ to $\mathrm{C}-4$ and C-8a. That another portion of the molecule was a 5-methylfuran-3(2H)-one ring was substantiated by the COSY correlation (Table 3, Figure S32) from the methyl singlet at $\delta_{\mathrm{H}} 2.31$ to $\mathrm{H}-3^{\prime}\left(\delta_{\mathrm{H}} 5.68, \mathrm{~d}, J=0.6 \mathrm{~Hz}\right)$, as well as the HMBC correlations (Table 3, Figure S34) from H-3 ${ }^{\prime}$ to C-3 $\left(\delta_{C} 86.3\right), C-2^{\prime}\left(\delta_{C} 191.4\right), C-4^{\prime}\left(\delta_{C} 198.3\right)$, and from the methyl singlet at $\delta_{\mathrm{H}} 2.31$ to $C-2^{\prime}$ and $C-3^{\prime}\left(\delta_{\mathrm{C}} 103.8\right)$. Finally, the 5-methylfuran-3(2H)-one moiety and the 6,7-dihydroxy-2,3-dihydro-4H-1-benzopyran-4-one were connected through $\mathrm{C}-3$ since the HMBC spectrum exhibited correlations from $\mathrm{H}-2\left(\delta_{\mathrm{H}} 4.49, \mathrm{~d}, J=12.4 \mathrm{~Hz}\right)$ to C-3 and C- $4^{\prime}$, and from $\mathrm{H}-3^{\prime}$ to $\mathrm{C}-3$. Therefore, the planar structure of 4 corresponds to $5^{\prime}$-methyl-2H,3' $\mathrm{H}, 4 \mathrm{H}$-spiro [1-benzopyran-3,2'-furan]-3', 4-dione. Since 4 was obtained as a suitable crystal, an X-ray analysis was carried out to determine the absolute configuration of the stereogenic carbon (C-3).

Table 3. The ${ }^{1} \mathrm{H}$ and ${ }^{13} \mathrm{C}$ NMR (DMSO- $d_{6}, 300.13$ and $75.4 \mathrm{MHz}$ ) and HMBC assignment for 4.

\begin{tabular}{ccccc}
\hline Position & $\boldsymbol{\Delta}_{\mathbf{c}}$, Type & $\delta_{\mathbf{H}},(\boldsymbol{J}$ in Hz) & COSY & HMBC \\
\hline $2 \mathrm{a}$ & $69.8, \mathrm{CH}_{2}$ & $4.49, \mathrm{~d}(12.4)$ & $2 \mathrm{~b}$ & $\mathrm{C}-4,4^{\prime}, 8 \mathrm{a}$ \\
$2 \mathrm{~b}$ & $4.63, \mathrm{~d}(12.4)$ & $2 \mathrm{a}$ & $\mathrm{C}-3,4,4^{\prime}, 8 \mathrm{a}-$ \\
3 & $86.3, \mathrm{C}$ & - & - & - \\
4 & $181.6, \mathrm{CO}$ & - & - & - \\
$4 \mathrm{a}$ & $111.1, \mathrm{C}$ & - & - & - \\
5 & $110.3, \mathrm{CH}$ & $7.05, \mathrm{~s}$ & - & $\mathrm{C}-4,6,7,8 \mathrm{a}$ \\
6 & $141.9, \mathrm{C}$ & - & - & - \\
7 & $155.9, \mathrm{C}$ & - & - & - \\
8 & $103.2, \mathrm{CH}$ & $6.41, \mathrm{~s}$ & - & $\mathrm{C}-4,4 \mathrm{a}, 6,7,8 \mathrm{a}$ \\
$8 \mathrm{a}$ & $156.9, \mathrm{C}$ & - & - & - \\
$2^{\prime}$ & $191.4, \mathrm{C}$ & - & - & - \\
$3^{\prime}$ & $103.8, \mathrm{CH}$ & $5.68, \mathrm{~d}(0.8)$ & $5^{\prime}$ & $\mathrm{C}-2^{\prime}, 3,4^{\prime}$ \\
$4^{\prime}$ & $198.3, \mathrm{CO}$ & - & - & - \\
$5^{\prime}$ & $16.4, \mathrm{CH} 3$ & $2.31, \mathrm{~s}$ & $3^{\prime}$ & $\mathrm{C}-2^{\prime}, 3^{\prime}$ \\
$\mathrm{OH}$ & - & $10.01, \mathrm{brs}$ & - & - \\
\hline
\end{tabular}

The ORTEP view, shown in Figure 5, not only confirmed the proposed structure for 4 but also determined unequivocally the absolute configuration of $\mathrm{C}-3$ as $3 S$. Therefore, the absolute structure of 4 is (3S)-6,7-dihydroxy-5'-methyl-3' $H, 4 H$-spiro[chromene-3, $2^{\prime}$-furan]- $3^{\prime}, 4$-dione, which was named erubescenschromone A. 


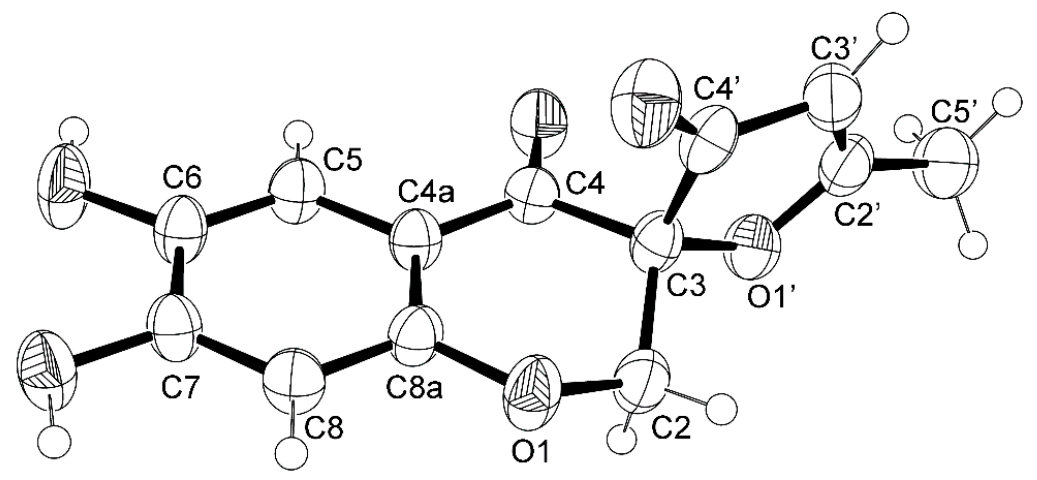

Figure 5. The Ortep view of 4.

Compound 5 was isolated as a white solid ( $\left.\mathrm{mp} 276-277^{\circ} \mathrm{C}\right)$, and displayed its (+)-HRESIMS $m / z$ at $305.0667[\mathrm{M}+\mathrm{H}]^{+}$, (calculated 305.0661 for $\mathrm{C}_{15} \mathrm{H}_{13} \mathrm{O}_{7}$ ). Therefore, its molecular formula was established as $\mathrm{C}_{15} \mathrm{H}_{12} \mathrm{O}_{7}$, indicating ten degrees of unsaturation. The IR spectrum exhibited absorption bands for hydroxyl $\left(3446 \mathrm{~cm}^{-1}\right)$, conjugated ketone carbonyls $\left(1719,1646 \mathrm{~cm}^{-1}\right)$, aromatic $\left(1560,1541 \mathrm{~cm}^{-1}\right)$, olefin $\left(1618 \mathrm{~cm}^{-1}\right)$ and ether $\left(1276 \mathrm{~cm}^{-1}\right)$ groups. However, its ${ }^{13} \mathrm{C}$ NMR spectrum (Table 4, Figure S36) displayed only fourteen carbon signals which, in combination with DEPTs and HSQC spectra (Figure S37), can be classified as two ketone carbonyls $\left(\delta_{C} 198.2\right.$ and 173.4), one conjugated carboxyl carbonyl $\left(\delta_{C} 167.1\right)$, three oxyquaternary $\operatorname{sp}^{2}\left(\delta_{C} 157.1,152.8,143.2\right)$, two quaternary $\mathrm{sp}^{2}\left(\delta_{C} 117.4\right.$ and 112.0$)$, one oxymethine $\mathrm{sp}^{2}\left(\delta_{C} 158.9\right)$, three methine $\mathrm{sp}^{2}\left(\delta_{C} 134.9\right.$, 128.7, 104.0), one methoxyl $\left(\delta_{C} 61.0\right)$ and one methyl $\left(\delta_{C} 27.5\right)$ carbons. The ${ }^{1} \mathrm{H}$ NMR spectrum (Table 4, Figure S35) exhibited four singlets of aromatic/olefinic protons at $\delta_{\mathrm{H}} 8.73(1 \mathrm{H}), 7.35(2 \mathrm{H})$, $7.03(1 \mathrm{H})$, one methoxyl singlet at $\delta_{\mathrm{H}} 3.75$ and one methyl singlet at $\delta_{\mathrm{H}} 2.29$. That 5 consists of a 7-hydroxy-6-methoxy-4-oxo-4H-chromene-5-carboxylic acid nucleus, with a substituent on C-3, was supported by the HMBC correlations (Table 4, Figure S38) from H-2 $\left(\delta_{\mathrm{H}} 8.73\right)$ to $\mathrm{C}-4\left(\delta_{\mathrm{C}} 173.4\right)$, $\mathrm{C}-8 \mathrm{a}\left(\delta_{\mathrm{C}} 152.8\right)$ and C-3 $\left(\delta_{\mathrm{C}} 117.4\right) ; \mathrm{H}-8\left(\delta_{\mathrm{H}} 7.03\right)$ to $\mathrm{C}-4 \mathrm{a}\left(\delta_{\mathrm{C}} 112.0\right), \mathrm{C}-6\left(\delta_{\mathrm{C}} 143.2\right), \mathrm{C}-7\left(\delta_{\mathrm{C}} 157.1\right)$, and $\mathrm{C}-8 \mathrm{a}$, from $\mathrm{OCH}_{3}-6\left(\delta_{\mathrm{H}} 3.75\right)$ to $\mathrm{C}-6$, as well as the carbon chemical shift value of $\mathrm{OCH}_{3}-6\left(\delta_{\mathrm{C}} 61.0\right)$, characteristic of the methoxyl group flanked by one oxygenated substituent and one carboxyl group. Like many other quaternary $\mathrm{sp}^{2}$ carbon linked to the carboxyl substituent, the intensity of the signal of $\mathrm{C}-5$ was not strong enough to be observed in the ${ }^{13} \mathrm{C}$ NMR spectrum. Moreover, since there is no proton two or three bonds away from C-5, it was not possible to localize the C-5 signal in the HMBC spectrum. The existence of a 3-oxobut-1-en-1-yl substituent was supported by the presence of a singlet of two protons at $\delta_{\mathrm{H}} 7.35(\mathrm{H}-10$ and $\mathrm{H}-11)$ which, through the HSQC spectrum, connected to the two methine $\mathrm{sp}^{2}$ carbons at $\delta_{\mathrm{C}} 134.9(\mathrm{C}-10)$ and $\delta_{\mathrm{C}} 128.7$ (C-11), as well as the HMBC correlations from H-10/H-11 to the ketone carbonyl carbon at $\delta_{\mathrm{C}} 198.2(\mathrm{C}-12)$, and from the methyl singlet at $\delta_{\mathrm{H}} 2.29\left(\mathrm{H}_{3}-13\right)$ to $\mathrm{C}-12$ and C-11. That the 3-oxobut-1-en-1-yl substituent was on C-3 was also supported by the HMBC correlations (Table 4, Figure S38) from H-10 to C-2 and C-4 as well as from H-2 to C-10. Therefore, the structure of 5 was elucidated as 7-hydroxy-6-methoxy-4-oxo-3-[3-oxobut-1-en-1-yl]-4H-chromene-5-carboxylic acid. The literature search revealed that 5 has never been previously reported; however its structure and NMR data were very similar to those of PI-4, a fungal metabolite first isolated by Arai et al. [16] from the mycelium of Penicillium italicum, a phyotoxic fungus which causes the blue-mold rot of fruits, and later by $\mathrm{Lu}$ et al. [17] from the crude extract of the fungus Chaetomium indicum (CBS.860.68). The only difference between PI-4 and 5 is the substituent on C-6 which is a hydroxyl group in the former and a methoxyl group in the latter. Therefore, $\mathbf{5}$ is identified as 7-hydroxy-6-methoxy-4-oxo-3-[(1E)-3-oxobut-1-en-1-yl]-4H-chromene-5-carboxylic acid. 
Table 4. The ${ }^{1} \mathrm{H}$ and ${ }^{13} \mathrm{C}$ NMR (DMSO- $d_{6}, 500.13$ and $125.4 \mathrm{MHz}$ ) and HMBC assignment for 5 .

\begin{tabular}{cccc}
\hline Position & $\delta_{\mathrm{C},}$, Type & $\delta_{\mathbf{H}},(\mathrm{J}$ in Hz) & HMBC \\
\hline 2 & $158.9, \mathrm{CH}$ & $8.73, \mathrm{~s}$ & $\mathrm{C}-3,4,8 \mathrm{a}, 10$ \\
3 & $117.4, \mathrm{C}$ & - & - \\
4 & $173.4, \mathrm{CO}$ & - & - \\
$4 \mathrm{a}$ & $112.0, \mathrm{C}$ & - & - \\
5 & $*$ & - & - \\
6 & $143.2, \mathrm{C}$ & - & - \\
7 & 157.1 & - & - \\
8 & $104.0, \mathrm{CH}$ & $7.03, \mathrm{~s}$ & - \\
$8 \mathrm{a}$ & $152.8, \mathrm{C}$ & - & - \\
9 & $167.1, \mathrm{CO}$ & - & - \\
10 & $134.9, \mathrm{CH}$ & $7.35, \mathrm{~s}$ & $2,4,12$ \\
11 & $128.7, \mathrm{CH}$ & $7.35, \mathrm{~s}$ & 3 \\
12 & $198.2, \mathrm{CO}$ & - & - \\
13 & $17.5, \mathrm{CH}$ & $2.29, \mathrm{~s}$ & 11,12 \\
$\mathrm{OCH}_{3}-6$ & $61.0, \mathrm{CH}$ & $3.75, \mathrm{~s}$ & 6 \\
\hline
\end{tabular}

The structure of 5 and the trans double bond between C-10 and C-11 are confirmed by X-ray analysis, as shown in the ORTEP view in Figure 6.

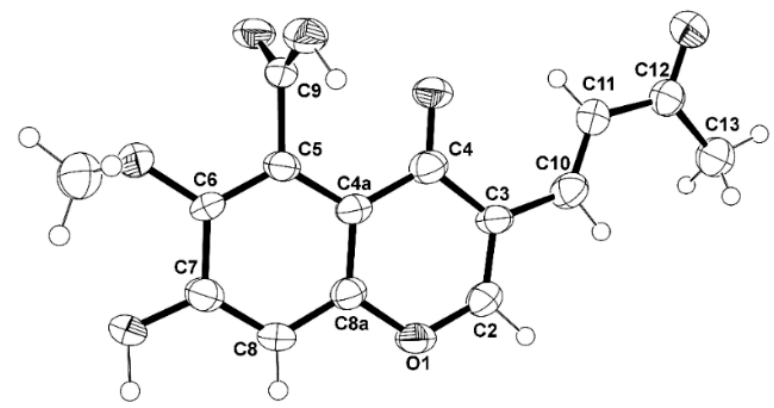

Figure 6. The Ortep view of 5 .

Compound 6 was isolated as a pale yellow viscous oil, and its molecular formula $\mathrm{C}_{26} \mathrm{H}_{20} \mathrm{O}_{11}$ was established based on its (+)-HRESIMS $m / z 509.1085[\mathrm{M}+\mathrm{H}]^{+}$, (calculated 509.1084 for $\mathrm{C}_{26} \mathrm{H}_{21} \mathrm{O}_{11}$ ), indicating twelve degrees of unsaturation. The IR spectrum showed absorption bands for hydroxyl $\left(3443 \mathrm{~cm}^{-1}\right)$, ketone carbonyls $\left(1731,1715 \mathrm{~cm}^{-1}\right)$, conjugated ketone carbonyls $\left(1697,1648 \mathrm{~cm}^{-1}\right)$, aromatic $\left(1634,1556,1596 \mathrm{~cm}^{-1}\right)$, and ether $\left(1261 \mathrm{~cm}^{-1}\right)$ groups. The ${ }^{13} \mathrm{C}$ NMR spectrum (Table 5, Figure S40) exhibited twenty six carbon signals which can be classified, according to the DEPTs and HSQC spectra (Table 5, Figure 542$)$ as two ketone carbonyls $\left(\delta_{C} 204.6,200.9\right)$, two conjugated ketone carbonyls $\left(\delta_{C} 185.3,172.2\right)$, ten quaternary $\mathrm{sp}^{2}\left(\delta_{\mathrm{C}} 161.3,156.0,155.4,152.5,150.2,144.7,141.4,115.1\right.$, $112.3,109.8)$, four methine $\operatorname{sp}^{2}\left(\delta_{C} 111.1,108.5,102.8,102.6\right)$, two oxyquatermary sp ${ }^{3}\left(\delta_{C} 61.9\right.$ and 78.2$)$, two methine $\mathrm{sp}^{3}\left(\delta_{C} 71.4\right.$ and 69.8), two methylene $\mathrm{sp}^{3}\left(\delta_{C} 67.2\right.$ and 33.4), and two tertiary methyl $\left(\delta_{C} 32.7\right.$ and 29.3$)$ carbons. The ${ }^{1} \mathrm{H}$ NMR spectrum (Table 5, Figure S39), in combination with the HSQC spectrum, displayed four singlets of aromatic protons at $\delta_{\mathrm{H}} 7.26,7.17,6.84$ and 6.37, two methine singlets at $\delta_{\mathrm{H}} 5.41$ and 5.23 , two doublets of the magnetically inequivalent oxymethylene protons at $\delta_{\mathrm{H}} 4.36(\mathrm{~J}=12.8 \mathrm{~Hz})$ and $3.59(\mathrm{~J}=12.8 \mathrm{~Hz})$, two doublets of the magnetically inequivalent methylene protons at $\delta_{\mathrm{H}} 3.47(J=19.2 \mathrm{~Hz})$ and $2.89(J=19.2 \mathrm{~Hz})$, in addition to two methyl singlets at $\delta_{\mathrm{H}} 2.16$ and 1.51. The presence of the 7,8-dihydroxy-3-methyl-3,4-dihydro- $1 \mathrm{H}, 10 \mathrm{H}$-pyrano[4,3-b]chromen-10-one moiety was substantiated by the HMBC correlations (Table 5, Figure S43) from $\mathrm{H}-5\left(\delta_{\mathrm{H}} 7.26, \mathrm{~s} ; \delta_{\mathrm{C}} 108.0\right)$ to $\mathrm{C}-4\left(\delta_{\mathrm{C}} 172.2\right), \mathrm{C}-8 \mathrm{a}\left(\delta_{\mathrm{C}} 152.5\right), \mathrm{C}-7\left(\delta_{\mathrm{C}} 150.2\right)$, and C-6 $(144.7) ; \mathrm{H}-8\left(\delta_{\mathrm{H}} 6.84, \mathrm{~s} ; \delta_{\mathrm{C}} 102.8\right)$ to $\mathrm{C}-4$, 
C-8a, C-7, C-6, C-4a $\left(\delta_{\mathrm{C}} 115.1\right) ; \mathrm{H}-12\left(\delta_{\mathrm{H}} 5.41, \mathrm{~s} ; \delta_{\mathrm{C}} 71.4\right)$ to C-4, C-2 $\left(\delta_{\mathrm{C}} 161.3\right), \mathrm{C}-3\left(\delta_{\mathrm{C}} 112.3\right), \mathrm{C}-10$ $\left(\delta_{C} 78.2\right)$, and from Me-13 $\left(\delta_{\mathrm{H}} 1.51, \mathrm{~s} ; \delta_{\mathrm{C}} 29.3\right)$ to $\mathrm{C}-2, \mathrm{C}-10$, and $\mathrm{C}-9\left(\delta_{\mathrm{C}} 33.4\right)$. Another portion of the molecule was identified as 3,3-disubstituted 6,7-dihydroxy-2,3-dihydro-4H-1-benzopyran-4-one, based on the HMBC correlations from $\mathrm{H}-5^{\prime}\left(\delta_{\mathrm{H}} 7.17, \mathrm{~s} ; \delta_{\mathrm{C}} 111.1\right)$ to $\mathrm{C}-4^{\prime}\left(\delta_{\mathrm{C}} 185.3\right), \mathrm{C}-8^{\prime} \mathrm{a}$ $\left(\delta_{\mathrm{C}} 156.0\right), \mathrm{C}-7^{\prime}\left(\delta_{\mathrm{C}} 155.4\right), \mathrm{C}-6^{\prime}\left(\delta_{\mathrm{C}} 141.4\right) ; \mathrm{H}-8^{\prime}\left(\delta_{\mathrm{H}} 6.37, \mathrm{~s} ; \delta_{\mathrm{C}} 102.6\right)$ to $\mathrm{C}-4^{\prime}, \mathrm{C}-8^{\prime} \mathrm{a}, \mathrm{C}-6^{\prime}$ and $\mathrm{C}-4^{\prime}$ a $\left(\delta_{\mathrm{C}} 109.8\right)$, as well as from $\mathrm{H}_{2}-2^{\prime}\left(\delta_{\mathrm{H}} 4.36, J=12.8 \mathrm{~Hz} / 3.59, J=12.8 \mathrm{~Hz}\right)$ to $\mathrm{C}-4^{\prime}, \mathrm{C}-8^{\prime}$ a and $C-3^{\prime}\left(\delta_{C}\right.$ 61.9). That the disubstituted 6,7-dihydroxy-2,3-dihydro-4H-1-benzopyran-4-one was connected to the 7,8-dihydroxy-3-methyl-3,4-dihydro- $1 H, 10 H$-pyrano[4,3- $b$ ]chromen-10-one moiety, through $\mathrm{C}-3^{\prime}$ of the former and $\mathrm{C}-12$ of the latter, was confirmed by the HMBC correlations from $\mathrm{H}-12$ to $\mathrm{C}-3^{\prime}$ and $\mathrm{H}_{2}-2^{\prime}$ to $\mathrm{C}-12$. Moreover, since the HMBC spectrum also exhibited correlations from $\mathrm{H}-12$ and $\mathrm{H}_{2}-2^{\prime}$ to the ketone carbonyl carbon at $\delta_{\mathrm{C}} 200.9$ (C-14), from H-15 $\left(\delta_{\mathrm{H}} 5.23, \mathrm{~s} ; \delta_{\mathrm{C}} 69.8\right)$ to $\mathrm{C}-9, \mathrm{C}-10\left(\delta_{\mathrm{C}} 78.2\right), \mathrm{C}-14$, and from Me-13 to C-15, the 7,8-dihydroxy-3-methyl-3,4-dihydro- $1 H, 10 H$-pyrano[4,3-b]chromen-10-one moiety was connected through $\mathrm{C}-10$ and $\mathrm{C}-15$ of the oxan-4-one ring. The acetyl group on $\mathrm{C}-15$ was corroborated by the HMBC correlations from Me-17 $\left(\delta_{\mathrm{H}} 2.16, \mathrm{~s} ; \delta_{\mathrm{C}} 32.7\right)$ to $\mathrm{C}-15$ and the carbonyl carbon at $\delta_{\mathrm{C}} 204.6(\mathrm{C}-16)$, as well as from H-15 to C-16. Taking together the molecular formula, the NMR data, and the HMBC correlations, the planar structure of 6 was unambiguously established. In order to determine the relative configurations of the stereogenic carbons C-10, C-12, C-15 and C- $3^{\prime}$, the ROESY spectrum was obtained. The ROESY spectrum (Figure S44) exhibited strong correlations from Me-13 $\left(\delta_{\mathrm{H}} 1.51, \mathrm{~s}\right)$ to $\mathrm{H}-15\left(\delta_{\mathrm{H}} 5.23, \mathrm{~s}\right)$ and the methylene proton at $\delta_{\mathrm{H}} 2.89, \mathrm{~d}(J=19.2 \mathrm{~Hz})$, implying that these three protons are on the same face. Additionally, $\mathrm{H}-15$ also shows a correlation with Me-17 $\left(\delta_{\mathrm{H}} 2.16\right.$, s). Since the pyran ring and the oxan-4-one ring of the 9-oxabicyclo[3.3.1]nonan-3-one ring system are in a rigid half-chair conformation, Me-13 must be in a pseudoequatorial position while the methylene proton at $\delta_{\mathrm{H}} 2.89, \mathrm{~d}(\mathrm{~J}=19.2 \mathrm{~Hz})$ and $\mathrm{H}-15$ are in a pseudoaxial position. Therefore, the acetyl group on C-15 must be in a pseudoequatorial position. This was confirmed by the higher chemical shift value $\left(\delta_{\mathrm{H}}\right.$ $3.47, \mathrm{~d}, J=19.2 \mathrm{~Hz}$ ) of the pseudoequatorial $\mathrm{H}-9$ as it is in the deshielding zone of the carbonyl (C-16) of the acetyl group. On the other hand, $\mathrm{H}-12\left(\delta_{\mathrm{H}} 5.41\right.$, s) showed a weak correlation to one of $\mathrm{H}-2^{\prime}$ at $\delta_{\mathrm{H}} 3.59, \mathrm{~d}(J=12.9 \mathrm{~Hz})$. Therefore both of these protons should be in the pseudoequatorial position since the pseudoaxial $\mathrm{H}-2^{\prime}\left(\delta_{\mathrm{H}} 4.36, \mathrm{~d}, J=12.9 \mathrm{~Hz}\right)$ is under the anisotropic effect (deshielding) of the carbonyl at C-14 of ring D. With these ROESY correlations, the relative configurations of C-10, 12, 15, and $3^{\prime}$ were proposed as $10 S^{*}, 12 S^{*}, 15 S^{*}$, and $3^{\prime} S^{*}$. However, it is necessary to determine the absolute configurations of these stereogenic carbons.

Since 6 could not be obtained as a suitable crystal for an X-ray analysis, the determination of its stereogenic carbons had to be carried out by comparison of the calculated and experimental ECD spectra. Although the ROESY correlations pointed to the relative configuration of C-10 and C-15 as $10 S, 15 S$, it is possible that it can be $10 R, 15 R$, thus reducing its number of possible configurations from 16 (eight pairs of diastereoisomers) to eight (four pairs of diastereoisomers). Hence, four computational models were constructed by combining the two configurations of $\mathrm{C}-3^{\prime}$ with the two of C-12. The conformational analysis of 6 by molecular mechanics (MM2 and MMFF95 force fields) focused on combinations of hydroxyl $120^{\circ}$ rotations and rings conformations. Most diastereoisomers did not show ring conformational freedom which limited the number of models to compute. The most stable APFD/6-31G conformation of 6 whose absolute configurations of C-10, C-12, C-15, and C-3' are $10 S, 12 S, 15 S, 3^{\prime} S$, as deduced from ROESY correlations, is shown in Figure 7. 
Table 5. The ${ }^{1} \mathrm{H}$ and ${ }^{13} \mathrm{C}$ NMR (DMSO- $d_{6}, 500.13$ and $125.4 \mathrm{MHz}$ ) and HMBC assignment for 6 .

\begin{tabular}{|c|c|c|c|c|}
\hline Position & $\delta_{C}$, Type & $\delta_{\mathrm{H}},(J$ in $\mathrm{Hz})$ & COSY & НМВС \\
\hline 2 & 161.3, C & - & - & - \\
\hline 3 & 112.3, C & - & - & - \\
\hline 4 & $172.2, \mathrm{CO}$ & - & - & - \\
\hline $4 a$ & $115.1, \mathrm{C}$ & - & - & - \\
\hline 5 & 108.0, $\mathrm{CH}$ & $7.26, \mathrm{~s}$ & - & $C-4,6,7,8 \mathrm{a}$ \\
\hline 6 & $144.7, \mathrm{C}$ & - & - & - \\
\hline 7 & $150.2, \mathrm{C}$ & - & - & - \\
\hline 8 & $102.8, \mathrm{CH}$ & $6.84, \mathrm{~s}$ & - & $C-4,4 a, 6,7,8 a$ \\
\hline $8 a$ & $152.5, \mathrm{C}$ & & - & - \\
\hline $9 \alpha$ & & $3.47, \mathrm{~d}(19.2)$ & $\mathrm{H}-9 \beta$ & $C-2,3,10,13,15$ \\
\hline $9 \beta$ & $33.4 \mathrm{CH}_{2}$ & $2.98, \mathrm{~d}(19.2)$ & $\mathrm{H}-9 \alpha$ & C $-2,3,10,13,15$ \\
\hline 10 & $78.2, \mathrm{C}$ & - & - & - \\
\hline 12 & $71.4, \mathrm{CH}$ & $5.41, \mathrm{~s}$ & - & $\mathrm{C}-2,3,3^{\prime}, 4,4^{\prime}, 10,14$ \\
\hline 13 & $29.3, \mathrm{CH}_{3}$ & $1.51, \mathrm{~s}$ & - & $C-2,9,10,14,15$ \\
\hline 14 & $200.9, \mathrm{CO}$ & - & - & - \\
\hline 15 & $69.8, \mathrm{CH}$ & $5.23, \mathrm{~s}$ & $\mathrm{H}-17$ & C- $9,10,13,14,16$ \\
\hline 16 & 204.6, CO & - & - & - \\
\hline 17 & $32.7, \mathrm{CH}_{3}$ & $2.16, \mathrm{~s}$ & $\mathrm{H}-15$ & $C-15,16$ \\
\hline $2^{\prime} \alpha$ & & $4.36, \mathrm{~d}(12.8)$ & $\mathrm{H}-2^{\prime} \beta$ & $\mathrm{C}-3^{\prime}, 4,8^{\prime} \mathrm{a}, 12,14$ \\
\hline $2^{\prime} \beta$ & $67.7, \mathrm{CH}_{2}$ & $3.59, \mathrm{~d}(12.8)$ & $\mathrm{H}-2^{\prime} \alpha, 15$ & $C-3^{\prime}, 4,8^{\prime} a, 12,14$ \\
\hline $3^{\prime}$ & $61.9, \mathrm{C}$ & - & - & - \\
\hline $4^{\prime}$ & $185.3, \mathrm{CO}$ & - & - & - \\
\hline $4^{\prime} \mathrm{a}$ & $109.8, \mathrm{C}$ & - & - & - \\
\hline $5^{\prime}$ & $111.1, \mathrm{CH}$ & $7.17, \mathrm{~s}$ & - & $\mathrm{C}-4^{\prime}, 6^{\prime}, 7^{\prime}, 8^{\prime} \mathrm{a}$ \\
\hline $6^{\prime}$ & 141.1, C & - & - & - \\
\hline $7^{\prime}$ & $155.4, \mathrm{C}$ & - & - & - \\
\hline $8^{\prime}$ & 102.6, $\mathrm{CH}$ & $6.37, \mathrm{~s}$ & - & $\mathrm{C}-4^{\prime}, 4^{\prime} \mathrm{a}, 6^{\prime}, 8^{\prime} \mathrm{a}$ \\
\hline $8^{\prime} \mathrm{a}$ & 156.0, C & - & - & - \\
\hline
\end{tabular}

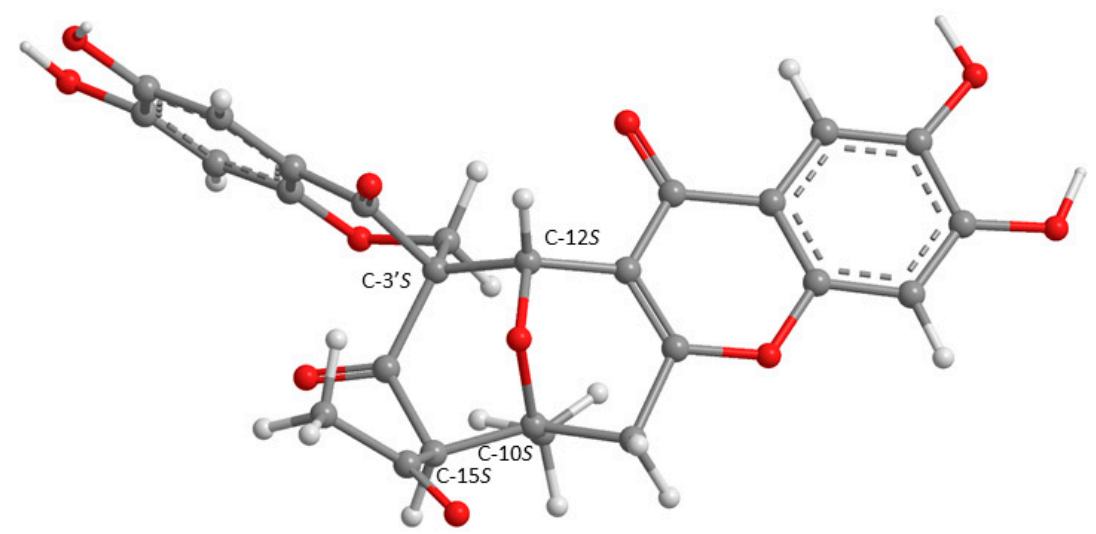

Figure 7. The most stable APFD/6-31G conformation of 6, presented with the absolute configuration found by spectrometric methods.

All conformations were energetically minimized and ranked using a DFT model. The lowest energy ones, representing at least $95 \%$ of the model Boltzmann population, were used to calculate the expected Boltzmann-averaged ECD spectra of the four 6 diastereoisomers. The fitting between the experimental and calculated spectra is presented in Figure 8, showing that the 6 is the C-10S, C-12S, C-3'S, C-15S enantiomer. 

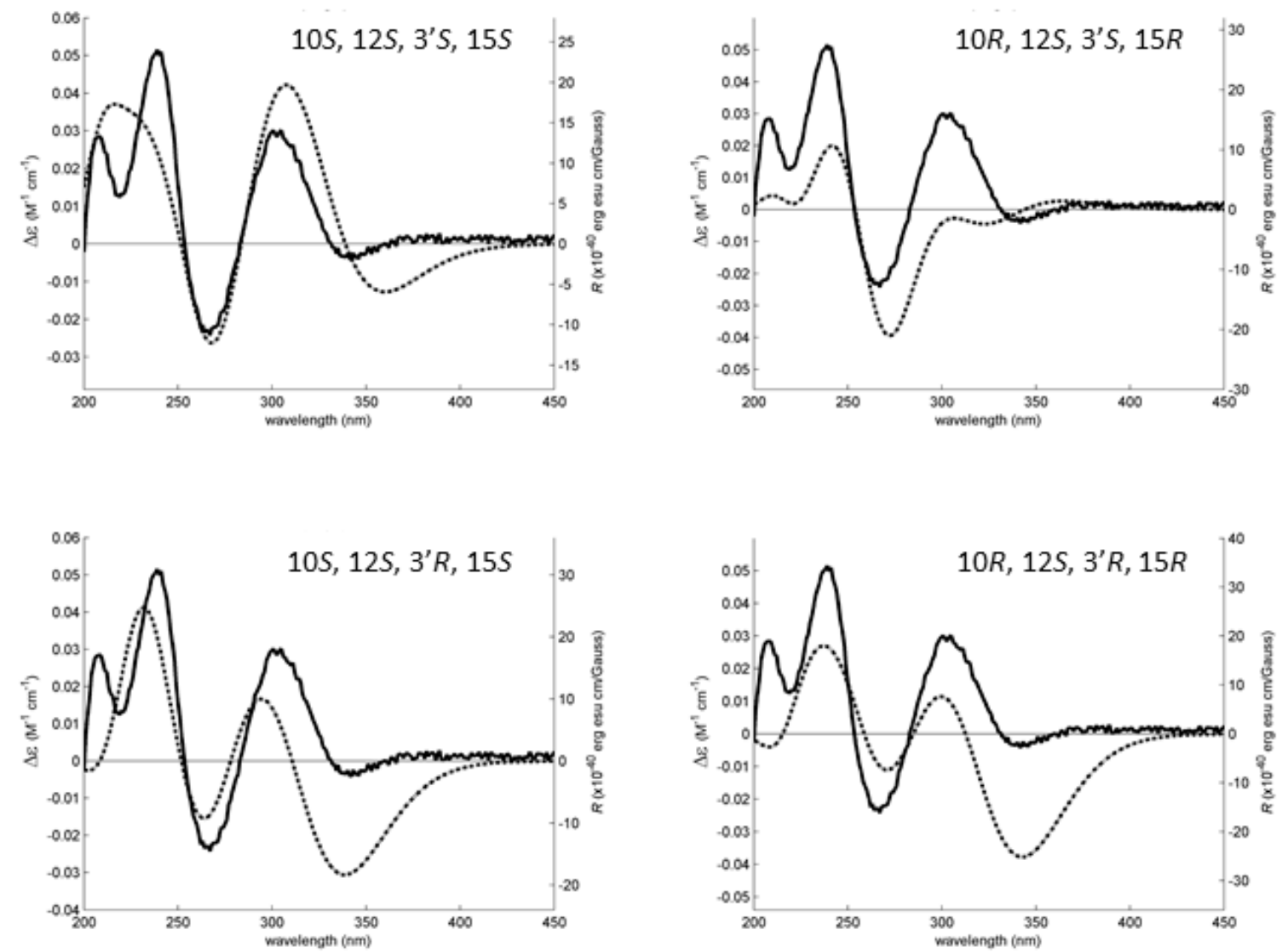

Figure 8. The experimental (solid line, left axes) and simulated (dotted line, right axes) ECD spectra of four diastereoisomers of $\mathbf{6}$. The best experimental-simulated fit belongs to the diastereoisomer with the absolute configuration $10 S, 12 S, 3^{\prime} S, 15 S$. The theoretical ECD spectra of the enantiomers of the presented diastereoisomers are the exact inversions of the ones depicted here and do not fit the experimental data.

The literature search revealed that $\mathbf{6}$ has never been previously reported and therefore it is a new compound which was named erubescenschromone B.

Compound 7 was isolated as a pale yellow oil and the (+)-HRESIMS showed the $[\mathrm{M}+\mathrm{H}]^{+}$peak at $m / z 509.1085$ (calculated 509.1084 for $\mathrm{C}_{26} \mathrm{H}_{21} \mathrm{O}_{11}$ ). Therefore, its molecular formula is $\mathrm{C}_{26} \mathrm{H}_{20} \mathrm{O}_{11}$, indicating eighteen degrees of unsaturation. The IR spectrum showed absorption bands for hydroxyl $\left(3491,3376 \mathrm{~cm}^{-1}\right)$, conjugated ketone carbonyls $\left(1679,1661 \mathrm{~cm}^{-1}\right)$, olefin $\left(1648 \mathrm{~cm}^{-1}\right)$, aromatic $(3108$, $\left.1578,1523 \mathrm{~cm}^{-1}\right)$, and ether $\left(1206 \mathrm{~cm}^{-1}\right.$ ) groups. The ${ }^{13} \mathrm{C}$ NMR spectrum (Table 6, Figure S46) exhibited twenty six carbon signals which, in combination with DEPTs and HSQC spectra (Table 6, Figure S47), can be classified as three carbonyls $\left(\delta_{C} 202.8,183.6,173.5\right)$, fifteen quaternary sp ${ }^{2}\left(\delta_{C} 172.6,155.9,154.9\right.$, $154.2,152.1,150.7,144.3,141.6,138.0,132.4,129.5,118.6,113.5,1119,103.9)$, five methine $\mathrm{sp}^{2}\left(\delta_{C} 125.7\right.$, $110.5,108.7,103.3,103.1)$, one methylene $\mathrm{sp}^{3}\left(\delta_{C} 66.2\right)$ and two methyl $\left(\delta_{C} 32.4\right.$ and 16.6) carbons. The ${ }^{1} \mathrm{H}$ NMR spectrum (Table 6, Figure S45) exhibited five singlets of aromatic protons at $\delta_{\mathrm{H}} 8.00,7.45$, $7.19,6.93$, and 6.34; a singlet of oxymethylene protons at $\delta_{\mathrm{H}} 4.67(2 \mathrm{H})$ and two methyl singlets at $\delta_{\mathrm{H}} 2.71$ and 2.32. The presence of the 6,7-dihydroxy-2,3-dihydro- $4 H$-chromen-4-one moiety was corroborated by the HMBC correlations (Table 6, Figure S48) from $\mathrm{H}-5^{\prime}\left(\delta_{\mathrm{H}} 7.19, \mathrm{~s} ; \delta_{\mathrm{C}} 110.5\right)$ to $\mathrm{C}-4^{\prime}\left(\delta_{\mathrm{C}} 183.6\right)$, $\mathrm{C}-6^{\prime}\left(\delta_{\mathrm{C}} 155.9\right), \mathrm{C}-8^{\prime} \mathrm{a}\left(\delta_{\mathrm{C}} 154.9\right)$ and $\mathrm{C}-7^{\prime}\left(\delta_{\mathrm{C}} 141.6\right) ; \mathrm{H}-8^{\prime}\left(\delta_{\mathrm{H}} 6.34, \mathrm{~s} ; \delta_{\mathrm{C}} 103.3\right)$ to $\mathrm{C}-4^{\prime} \mathrm{a}\left(\delta_{\mathrm{C}} 111.9\right), \mathrm{C}-6^{\prime}$, $\mathrm{C}-7^{\prime}, \mathrm{C}-8^{\prime} \mathrm{a}$, and $\mathrm{H}_{2}-2^{\prime}\left(\delta_{\mathrm{H}} 4.67, \mathrm{~s} ; \delta_{\mathrm{C}} 66.2\right)$ to $\mathrm{C}-3^{\prime}\left(\delta_{\mathrm{C}} 103.9\right)$ and $\mathrm{C}-4^{\prime}\left(\delta_{\mathrm{C}} 183.6\right)$. That the substituent on $\mathrm{C}-3^{\prime}$ was an enolic exocyclic double bond was substantiated by the HMBC correlations from $\mathrm{H}_{2}-2^{\prime}$ to $C-3^{\prime}\left(\delta_{C} 103.9\right)$ and the enolic carbon $\left(C-9^{\prime}, \delta_{C} 172.6\right)$. Another moiety was established as 7 -substituted 5-acetyl-2,3-dihydroxy-6-methyl-9H-xanthen-9-one since the HMBC spectrum showed correlations 
from $\mathrm{H}-5\left(\delta_{\mathrm{H}} 6.93, \mathrm{~s} ; \delta_{\mathrm{C}} 103.1\right)$ to $\mathrm{C}-7\left(\delta_{\mathrm{C}} 143.3\right), \mathrm{C}-8 \mathrm{a}\left(\delta_{\mathrm{C}} 113.5\right), \mathrm{C}-10 \mathrm{a}\left(\delta_{\mathrm{C}} 154.2\right) ; \mathrm{H}-8\left(\delta_{\mathrm{H}} 7.45, \mathrm{~s}\right.$; $\left.\delta_{\mathrm{C}} 108.7\right)$ to $\mathrm{C}-6\left(\delta_{\mathrm{C}} 150.7\right), \mathrm{C}-7, \mathrm{C}-9\left(\delta_{\mathrm{C}} 173.5\right), \mathrm{C}-10 \mathrm{a} ; \mathrm{H}-1\left(\delta_{\mathrm{H}} 8.00, \mathrm{~s} ; \delta_{\mathrm{C}} 125.7\right)$ to $\mathrm{C}-3\left(\delta_{\mathrm{C}} 138.0\right)$ and $\mathrm{C}-4 \mathrm{a}\left(\delta_{\mathrm{C}} 152.1\right) ; \mathrm{Me}-11\left(\delta_{\mathrm{H}} 2.32, \mathrm{~s} ; \delta_{\mathrm{C}} 16.6\right)$ to $\mathrm{C}-2\left(\delta_{\mathrm{C}} 129.5\right), \mathrm{C}-3, \mathrm{C}-4\left(\delta_{\mathrm{C}} 132.2\right)$. Since H-1 also showed the HMBC correlation to $\mathrm{C}^{-9}{ }^{\prime}$, the 5-acetyl-2,3-dihydroxy-6-methyl-9H-xanthen-9-one was linked to the 6,7-dihydroxy-2,3-dihydro- $4 \mathrm{H}$-chromen-4-one moiety through $\mathrm{C}-9^{\prime}$. An extensive literature search revealed that the structure of $\mathbf{7}$ is the same as that of the enol tautomer of the compound, named SPF-3059-30, isolated from the acetone extract of the mycelium of Penicillium sp. SPF-3050 (FERM BB-7663), cultured in the liquid medium [11]. However, the authors claimed that SPF-3050-30 was isolated as a mixture of keto-enol tautomers, as supported by the duplication of the ${ }^{1} \mathrm{H}$ and ${ }^{13} \mathrm{C}$ chemical shift values but without an assignment. The ${ }^{13} \mathrm{C}$ NMR data of SPF-3050-30 displayed forty one carbon signals, e.g., four signals for the methyl groups, three signals for the oxymethylene carbons, two signals for the carbonyl carbon of the acetyl group, two signals for the carbonyl of the chromone nucleus and two signals of the carbonyl of the xanthone moiety, etc., while its ${ }^{1} \mathrm{H}$ NMR data presented two methyl signals of the methyl group on the xanthone nucleus, two methyl signals for the acetyl group and nine signals of aromatic protons. On the contrary, the ${ }^{1} \mathrm{H}$ and ${ }^{13} \mathrm{C}$ NMR spectra of 7 in DMSO (Table 6, Figures S45 and S46) showed that it was present only in an enolic form. This is supported by the fact that the enolic form is stabilized by the hydrogen bonding between $\mathrm{OH}-\mathrm{9}^{\prime}$ and the carbonyl of the chromone moiety $\left(\mathrm{C}-4^{\prime}\right)$.

Table 6. The ${ }^{1} \mathrm{H}$ and ${ }^{13} \mathrm{C}$ NMR (DMSO- $d_{6}, 500.13$ and $125.4 \mathrm{MHz}$ ) and HMBC assignment for 7 .

\begin{tabular}{|c|c|c|c|}
\hline Position & $\delta_{C}$, Type & $\delta_{\mathrm{H}},(J$ in $\mathrm{Hz})$ & НМВС \\
\hline 1 & $125.7, \mathrm{CH}$ & $8.00, \mathrm{~s}$ & $C-3,4 a, 9^{\prime}$ \\
\hline 2 & $129.5, \mathrm{C}$ & - & - \\
\hline 3 & $138.0, \mathrm{C}$ & - & - \\
\hline 4 & $132.2, \mathrm{C}$ & - & - \\
\hline $4 \mathrm{a}$ & 152.1, C & - & - \\
\hline 5 & 103.1, CH & $6.93, \mathrm{~s}$ & $C-7,8 a, 10 a$ \\
\hline 6 & $150.9, \mathrm{C}$ & - & - \\
\hline 7 & $144.3, \mathrm{C}$ & - & - \\
\hline 8 & 108.7, C & $7.45, \mathrm{~s}$ & $\mathrm{C}-6,7,9,10 \mathrm{a}$ \\
\hline $8 a$ & $113.5, \mathrm{C}$ & - & - \\
\hline 9 & $173.5, \mathrm{CO}$ & - & - \\
\hline $9 a$ & $118.6, \mathrm{C}$ & - & - \\
\hline $10 \mathrm{a}$ & 154.2, C & - & - \\
\hline 11 & $16.6, \mathrm{CH}_{3}$ & $2.32, \mathrm{~s}$ & $C-2,3,4$ \\
\hline 12 & $202.8, \mathrm{CO}$ & - & - \\
\hline 13 & $32.4, \mathrm{CH}_{3}$ & $2.71, \mathrm{~s}$ & C-12 \\
\hline $2^{\prime}$ & $66.2, \mathrm{CH}_{2}$ & $4.67, \mathrm{~s}$ & $\mathrm{C}-3^{\prime}, 4^{\prime}, 8^{\prime} \mathrm{a}, 9^{\prime}$ \\
\hline $3^{\prime}$ & $103.9, \mathrm{C}$ & - & - \\
\hline $4^{\prime}$ & $183.6, \mathrm{CO}$ & - & - \\
\hline $4^{\prime} \mathrm{a}$ & $111.9, \mathrm{C}$ & - & - \\
\hline $5^{\prime}$ & $110.5, \mathrm{CH}$ & $7.19, \mathrm{~s}$ & $\mathrm{C}-4^{\prime}, 6^{\prime}, 7^{\prime}, 8^{\prime} \mathrm{a}$ \\
\hline $6^{\prime}$ & 155.9, C & - & - \\
\hline $7^{\prime}$ & $141.6, \mathrm{C}$ & - & - \\
\hline $8^{\prime}$ & 103.3, CH & $6.34, \mathrm{~s}$ & $\mathrm{C}-4^{\prime} \mathrm{a}, 6^{\prime}, 7,8^{\prime} \mathrm{a}$ \\
\hline $8^{\prime} \mathrm{a}$ & $154.9, \mathrm{C}$ & - & - \\
\hline $9^{\prime}$ & $172.6, \mathrm{C}$ & - & - \\
\hline
\end{tabular}

Compound 7 can be considered as a decarboxylated derivative of xanthofulvin, a semaphorin inhibitor isolated from the culture broth of the fungus Penicillium sp. SPF-3059 [18].

Compounds 1a-e, 2a, 3a, 4, 7-9 were evaluated for their antibacterial activity against Gram-negative and Gram-positive bacteria by disc diffusion method, and the MIC and MBC of several reference strains and multidrug-resistant isolates from the environment were also determined. In the disc diffusion assay, a halo of growth inhibition for all Gram-positive bacteria exposed to 8 
(Table 7) and for methicillin-resistant Staphylococcus aureus (MRSA) 66/1 exposed to 9 was detected. However, in the range of concentrations tested, it was only possible to determine MICs for 8 (Table 7), with MIC values of $8 \mathrm{mg} / \mathrm{mL}$ for E. faecalis ATCC 29212 and vancomycin-resistant E. faecalis (VRE) B3/101, $16 \mathrm{mg} / \mathrm{mL}$ for E. faecium ATCC 19434, and $32 \mathrm{mg} / \mathrm{mL}$ for E. faecium 1/6/63 (VRE) and S. aureus ATCC 29213. While it was not possible to determine the MBC for the other Gram-positive strains, the MBC for S. aureus ATCC 29213 was $64 \mathrm{mg} / \mathrm{mL}$ (Table 7). These results suggested that 8 might have a bacteriostatic effect.

Table 7. The antibacterial activity of 8 against a Gram-positive reference and multidrug-resistant strains. $\mathrm{MIC}$ and MBC are expressed in $\mathrm{mg} / \mathrm{mL}$.

\begin{tabular}{ccccccc}
\hline Strains & $\begin{array}{c}\text { E. faecalis } \\
\text { ATCC29212 }\end{array}$ & $\begin{array}{c}\text { E.faecium } \\
\text { ATCC19434 }\end{array}$ & $\begin{array}{c}\text { S. aureus } \\
\text { ATCC29213 }\end{array}$ & $\begin{array}{c}\text { E. faecalis } \\
\text { B3/101 (VRE) }\end{array}$ & $\begin{array}{c}\text { E. faecium } \\
\text { 1/6/63 (VRE) }\end{array}$ & $\begin{array}{c}\text { S. aureus 66/1 } \\
\text { (MRSA) }\end{array}$ \\
\hline Disc diffusion & + & + & + & + & + & + \\
MIC & 8 & 16 & 32 & 8 & 32 & $>64$ \\
MBC & $>64$ & $>64$ & 64 & $>64$ & $>64$ & $>64$ \\
\hline
\end{tabular}

MIC, minimal inhibitory concentration; MBC, minimal bactericidal concentration; VRE, vancomycin-resistant Enterococcus; MRSA, methicillin-resistant Staphylococcus aureus; (-), no inhibition halo; (+), 7-9 mm inhibition halo.

The ability of the tested compounds to prevent biofilm formation was evaluated on four reference strains by measuring the total biomass. For 8 , four concentrations ranging from $2 \times$ MIC to $\frac{1}{4}$ MIC were tested against E. faecalis ATCC 29212, E. faecium ATCC 19434 and S. aureus ATCC 29213. For the other compounds, since it was not possible to determine their MIC values, the highest concentration tested in the previous assays was used. The results were interpreted using a comparative classification that divides adherence capability of tested strains into four categories: (i) non-adherent, (ii) weakly adherent, (iii) moderately adherent, and (iv) strongly adherent [19]. OThe optical density cut-off value (ODc) for each microtiter plate was defined as three standard deviations above the mean OD of the negative control. The use of this classification, which uses the negative control as the starting point instead of using the positive control as a reference, reduces the risk of inconsistencies due to external factors that influence biofilm production [20]. The tested compounds did not inhibit the biofilm formation of S. aureus ATCC 29213, E. coli ATCC 25922, and P. aeruginosa ATCC 27853. However, the biofilm forming ability of E. faecalis ATCC 29212, which is classified as a strong biofilm producer, was impaired by 8 (MIC and $2 \times$ MIC) and 9 (Table 8 ). On the other hand, 8 was able to increase the biofilm production of a weak biofilm producer E. faecium ATCC 19434.

Table 8. The classification of the ability of E. faecalis ATCC 29212 to adhere to and form biofilm after exposure to 1a-e, 2a, 3a, 4, 7-9, in comparison to the untreated control.

\begin{tabular}{cccc}
\hline Compound & Concentration $(\mathbf{m g} / \mathbf{L})$ & OD $\pm \mathbf{S D}$ & Classification \\
\hline $\mathbf{1 a}$ & 64 & $1.205 \pm 0.025$ & strong \\
$\mathbf{1 b}$ & 64 & $1.547 \pm 0.218$ & strong \\
$\mathbf{1 c}$ & 64 & $1.673 \pm 0.308$ & strong \\
$\mathbf{1 d}$ & 64 & $1.522 \pm 0.308$ & strong \\
$\mathbf{1 e}$ & 32 & $1.378 \pm 0.378$ & strong \\
$\mathbf{2 a}$ & 64 & $1.136 \pm 0.138$ & strong \\
$\mathbf{3 a}$ & 64 & $2.128 \pm 0.248$ & strong \\
$\mathbf{4}$ & 64 & $0.867 \pm 0.280$ & strong \\
$\mathbf{7}$ & 64 & $1.192 \pm 0.239$ & strong \\
$\mathbf{8}$ & $16(2 \times \mathrm{MIC})$ & $0.089 \pm 0.002$ & weak \\
$\mathbf{8}$ & $8(\mathrm{MIC})$ & $0.099 \pm 0.006$ & weak \\
$\mathbf{8}$ & $4(1 / 2 \mathrm{MIC})$ & $1.884 \pm 0.220$ & strong \\
$\mathbf{8}$ & $2(1 / 4 \mathrm{MIC})$ & $2.358 \pm 0.416$ & strong \\
$\mathbf{9}$ & 64 & $0.263 \pm 0.014$ & moderate \\
None & 0 & $0.080 \pm 0.002$ & strong \\
\hline
\end{tabular}

$\mathrm{OD}=$ optical density; $\mathrm{SD}$ = standard deviation; The classification used is based on criteria in [19], Average OD value for negative control was found to be $0.055 \pm 0.002$, therefore the optical cut-off value (ODc) is equal to $0.055+(3 \times 0.002)=0.061 ; 2 \times \mathrm{ODc}=0.122 ; 4 \times \mathrm{ODc}=0.244$. 
The screening of a potential synergy between the tested compounds and clinically relevant antimicrobial drugs revealed a slight synergy, as determined by the disc diffusion assay (Table 9). Compound $\mathbf{1 b}$, in combination with cefotaxime (CTX), resulted in a small synergistic effect, as seen by a small increment in the zone of inhibition when compared to the inhibition halo of CTX alone in E. coli $\mathrm{SA} / 2$, an extended-spectrum $\beta$-lactamase producer (ESBL). A similar effect was observed for VRE E. faecalis B3/101 when $\mathbf{8}$ was combined with VAN. These results were confirmed by the checkerboard method or by determining the MIC for each antibiotic in the presence of a fixed concentration of each compound when it was not possible to determine a MIC value for the test compound. In the latter, the concentration of each compound used was the highest concentration tested in previous assays which did not inhibit the growth of the four multidrug-resistant strains under study. The effects observed using the disc diffusion assay were not replicated, however, when VRE E. faecalis B3/101 was exposed to 1d, 3a and 9, there was a two-fold reduction in the MIC of VAN. On the other hand, when ESBL E. coli SA/2 was exposed to 1c and 7, there was at least a two-fold increase in the MIC of CTX. When VRE E. faecium 1/6/63 was exposed to 9, there was a two-fold reduction in the MIC of VAN. On the contrary, when it was exposed to 1e, there was at least a two-fold increase in the MIC of VAN (Table 9). The differences in the results obtained using both techniques may be explained by different diffusion rates of each compound in the agar plates.

Thus, in terms of antibacterial activity, $\mathbf{8}$ is the most promising. Even though no synergy with VAN or OXA was found, this compound alone exhibited an antibiofilm activity against $E$. faecalis and antibacterial activity against the reference S. aureus, E. faecalis, and E. faecium strains. Most importantly, 8 showed antibacterial activity against both vancomycin-resistant $E$. faecalis and vancomycin-resistant E. faecium strains, a pathogen classified by WHO as high priority for the research and development of new antibiotics [21]. These results call for a more in-depth study of this compound.

Table 9. The combined effect of clinically used antibiotics with 1a-e, 2a, 3a, 4, 7-9 against multidrug-resistant strains. MICs are expressed in $\mathrm{mg} / \mathrm{mL}$.

\begin{tabular}{|c|c|c|c|c|c|c|c|c|}
\hline \multirow{3}{*}{ Compound } & \multirow{2}{*}{\multicolumn{2}{|c|}{$\frac{\text { E. coli } \mathrm{SA} / 2}{\text { CTX }}$}} & \multirow{2}{*}{\multicolumn{2}{|c|}{$\frac{\text { E. faecalis B3/101 }}{\text { VAN }}$}} & \multirow{2}{*}{\multicolumn{2}{|c|}{$\begin{array}{c}\text { E. faecium } 1 / 6 / 63 \\
\text { VAN }\end{array}$}} & \multirow{2}{*}{\multicolumn{2}{|c|}{$\begin{array}{c}\text { S. aureus } 66 / 1 \\
\text { OXA }\end{array}$}} \\
\hline & & & & & & & & \\
\hline & Disc Diffusion & MIC & Disc Diffusion & MIC & Disc Diffusion & MIC & Disc Diffusion & MIC \\
\hline Antibiotic & + & 512 & - & 1024 & - & 1024 & - & 64 \\
\hline Antibiotic + 1a & - & 512 & - & 1024 & - & 1024 & - & 64 \\
\hline Antibiotic $+\mathbf{1 b}$ & + & 512 & - & 1024 & - & 1024 & - & 64 \\
\hline Antibiotic $+1 c$ & - & $>512$ & - & 1024 & - & 1024 & - & 64 \\
\hline Antibiotic + 1d & - & 512 & - & 512 & - & 1024 & - & 64 \\
\hline Antibiotic $+1 \mathbf{e}$ & - & 512 & - & 1024 & - & $>1024$ & - & 64 \\
\hline Antibiotic $+2 \mathbf{a}$ & - & 512 & - & 1024 & - & 1024 & - & 64 \\
\hline Antibiotic $+3 a$ & - & 512 & - & 512 & - & 1024 & - & 64 \\
\hline Antibiotic +4 & - & 512 & - & 1024 & - & 1024 & - & 64 \\
\hline Antibiotic +7 & - & $>512$ & - & 1024 & - & 1024 & - & 64 \\
\hline Antibiotic +8 & - & 512 & + & $*$ & - & * & - & 64 \\
\hline Antibiotic +9 & - & 512 & - & 512 & - & 512 & - & 64 \\
\hline
\end{tabular}

MIC = minimal inhibitory concentration; $(-)=$ no inhibition halo or no increase in the inhibition halo; $(+)=$ halo of inhibition or increase of the inhibition halo by $2 \mathrm{~mm}$; CTX = cefotaxime; VAN = vancomycin; OXA = oxacillin.

* For this compound, the checkerboard assay was performed and, with FICI $=0.7$ for E. faecalis B3 $/ 101$ and FICI $=2$

for E. faecium 1/6/63, no interaction between 8 and VAN was found $(0.5<\mathrm{FICI} \leq 4$, 'no interaction').

\section{Experimental Section}

\subsection{General Experimental Procedures}

The melting points were determined on a Stuart Melting Point Apparatus SMP3 (Bibby Sterilin, Stone, Staffordshire, UK) and are uncorrected. Optical rotations were measured on an ADP410 Polarimeter (Bellingham + Stanley Ltd., Tunbridge Wells, Kent, UK). Infrared spectra were recorded in a $\mathrm{KBr}$ microplate in an FTIR spectrometer Nicolet iS10 from Thermo Scientific (Waltham, MA, USA) with a Smart OMNI-Transmission accessory (Software 188 OMNIC 8.3, Thermo Scientific, Waltham, MA, USA). ${ }^{1} \mathrm{H}$ and ${ }^{13} \mathrm{C}$ NMR spectra were recorded at ambient temperature on a Bruker 
AMC instrument (Bruker Biosciences Corporation, Billerica, MA, USA) operating at $\mathrm{f} 300$ or 500 and 75 or $125 \mathrm{MHz}$, respectively. High resolution mass spectra were measured with a Waters Xevo QToF mass spectrometer (Waters Corporations, Milford, MA, USA) coupled to a Waters Aquity UPLC system. A Merck (Darmstadt, Germany) silica gel $\mathrm{GF}_{254}$ was used for preparative TLC, and a Merck Si gel 60 $(0.2-0.5 \mathrm{~mm})$ was used for column chromatography.

\subsection{Fungal Material}

The fungus was isolated from the marine sponge Neopetrosia sp. which was collected, by scuba diving at a depth of 5-10 m, from the coral reef at Samaesan Island $\left(12^{\circ} 34^{\prime} 36.64^{\prime \prime} \mathrm{N}, 100^{\circ} 56^{\prime} 59.69^{\prime \prime} \mathrm{E}\right)$, Chonburi province, Thailand, in April 2014. The sponge was washed with $0.01 \%$ sodium hypochlorite solution for $1 \mathrm{~min}$, followed by sterilized seawater three times, and then dried on sterile filter paper under sterile aseptic condition. The sponge was cut into small pieces $(5 \mathrm{~mm} \times 5 \mathrm{~mm})$ and placed on Petri dish plates containing $15 \mathrm{~mL}$ potato dextrose agar (PDA) medium mixed with $300 \mathrm{mg} / \mathrm{L}$ of streptomycin sulfate, and incubated at $28^{\circ} \mathrm{C}$ for 7 days. The hyphal tips emerging from sponge pieces were individually transferred onto PDA slants and maintained as pure cultures at Kasetsart University Fungal Collection, Department of Plant Pathology, Faculty of Agriculture, Kasetsart University, Bangkok, Thailand, for further identification. The fungal strain KUFA0220 was identified as Penicillium erubescens, based on morphological characteristics such as colony growth rate and growth pattern on standard media, namely Czapek's agar, Czapek yeast autolysate agar, and malt extract agar. Microscopic characteristics including size, shape and ornamentation of conidiophores and spores were examined under a light microscope. This identification was confirmed by molecular techniques using Internal Transcribed Spacer (ITS) primers. DNA was extracted from young mycelia following a modified Murray and Thompson method [22]. Primer pairs ITS1 and ITS4 [23] were used for ITS gene amplification. PCR reactions were conducted on Thermal Cycler and the amplification process consisted of the initial denaturation at $95{ }^{\circ} \mathrm{C}$ for $5 \mathrm{~min}, 34$ cycles at $95^{\circ} \mathrm{C}$ for $1 \mathrm{~min}$ (denaturation), at $55^{\circ} \mathrm{C}$ for $1 \mathrm{~min}$ (annealing) and at $72{ }^{\circ} \mathrm{C}$ for $1.5 \mathrm{~min}$ (extension), followed by final extension at $72{ }^{\circ} \mathrm{C}$ for $10 \mathrm{~min}$. The PCR products were examined by agarose gel electrophoresis $(1 \%$ agarose with $1 \times \mathrm{TBE}$ buffer) and visualized under UV light after staining with ethidium bromide. DNA sequencing analyses were performed using the dideoxyribonucleotide chain termination method [24] by Macrogen Inc. (Seoul, Korea). The DNA sequences were edited using the FinchTV software (version 1.4, Geospiza Inc, Seattle, WA, USA) and submitted into the BLAST program for alignment and compared to fungal species in the NCBI database (http:/ / www.ncbi.nlm.nih.gov/). Its gene sequences were deposited in GenBank with accession number KY041867.

\subsection{Extraction and Isolation}

The fungus was cultured for one week at $28{ }^{\circ} \mathrm{C}$ in five Petri dishes (i.d. $90 \mathrm{~mm}$ ) containing $20 \mathrm{~mL}$ of potato dextrose agar per dish. The mycelial plugs ( $5 \mathrm{~mm}$ in diameter) were transferred to two $500 \mathrm{~mL}$ Erlenmeyer flasks containing $200 \mathrm{~mL}$ of potato dextrose broth, and incubated on a rotary shaker at $120 \mathrm{rpm}$ at $28^{\circ} \mathrm{C}$ for one week. Fifty $1000 \mathrm{~mL}$ Erlenmeyer flasks, each containing $300 \mathrm{~g}$ of cooked rice, were autoclaved at $121^{\circ} \mathrm{C}$ for $15 \mathrm{~min}$. After cooling to room temperature, $20 \mathrm{~mL}$ of a mycelial suspension of the fungus was inoculated per flask and incubated at $28^{\circ} \mathrm{C}$ for 30 days, after which $500 \mathrm{~mL}$ of ethyl acetate was added to each flask of the moldy rice and macerated for 7 days, and then filtered with Whatman No. 1 filter paper (GE Healthcare UK Limited, Buckinghamshire, UK). The ethyl acetate solutions were combined and concentrated under reduced pressure to yield $160 \mathrm{~g}$ of crude ethyl acetate extract which was dissolved in $500 \mathrm{~mL}$ of $\mathrm{CHCl}_{3}$ and then filtered with Whatman No. 1 filter paper. The chloroform solution was then washed with $\mathrm{H}_{2} \mathrm{O}(3 \times 500 \mathrm{~mL})$ and dried with anhydrous $\mathrm{Na}_{2} \mathrm{SO}_{4}$, filtered and evaporated under reduced pressure to give $112 \mathrm{~g}$ of the crude chloroform extract which was applied on a column of silica gel $(450 \mathrm{~g})$, and eluted with mixtures of petrol- $\mathrm{CHCl}_{3}$ and $\mathrm{CHCl}_{3}-\mathrm{Me}_{2} \mathrm{CO}$, wherein $250 \mathrm{~mL}$ fractions were collected as follow: Frs 1-147 (petrol- $\mathrm{CHCl}_{3}, 1: 1$ ), 148-223 (petrol- $\left.\mathrm{CHCl}_{3}, 3: 7\right), 224-230$ (petrol- $\left.\mathrm{CHCl}_{3}, 1: 9\right), 231-238\left(\mathrm{CHCl}_{3}\right), 239-452\left(\mathrm{CHCl}_{3}-\mathrm{Me}_{2} \mathrm{CO}\right.$, 
9:1), 453-512 ( $\left.\mathrm{CHCl}_{3}-\mathrm{Me}_{2} \mathrm{CO}, 7: 3\right), 512-546\left(\mathrm{Me}_{2} \mathrm{CO}, 7: 3\right)$. Frs 75-117 were combined (1.18 g) and applied on a column of silica gel ( $35 \mathrm{~g}$ ) and eluted with mixtures of petrol- $\mathrm{CHCl}_{3}$ and $\mathrm{CHCl}_{3}-\mathrm{Me}_{2} \mathrm{O}$, wherein $100 \mathrm{~mL}$ sfrs were collected as follow: Sfrs 1-20 (petrol), 21-33 (petrol- $\mathrm{CHCl}_{3}, 9: 1$ ), 34-48 (petrol- $\left.\mathrm{CHCl}_{3}, 7: 3\right), 49-59$ (petrol- $\left.\mathrm{CHCl}_{3}, 1: 9\right), 60-65$ (petrol- $\mathrm{CHCl}_{3}$ ), 66-80 $\left(\mathrm{CHCl}_{3}-\mathrm{Me}_{2} \mathrm{CO}, 9: 1\right.$ ), 81-106 $\left.\mathrm{CHCl}_{3}-\mathrm{Me}_{2} \mathrm{CO}, 7: 3\right), 107-120\left(\mathrm{Me}_{2} \mathrm{CO}\right)$. Sfrs 35-46 were combined (103.0 mg) and purified by TLC (Silica gel $\mathrm{G}_{254}, \mathrm{CHCl}_{3}: \mathrm{Me}_{2} \mathrm{CO}: \mathrm{HCO}_{2} \mathrm{H}, 97: 3: 0.01$ ) to give $50.2 \mathrm{mg}$ of $\beta$-sitostenone [3]. Frs 238-245 were combined $(1.75 \mathrm{~g})$ and precipitated in $\mathrm{MeOH}$ to give $202.1 \mathrm{mg}$ of 8 [12-14]. Frs 246-251 were combined ( $2.67 \mathrm{~g}$ ) and precipitated in $\mathrm{MeOH}$ to give $472.2 \mathrm{mg}$ of ergosterol 5,8-endoperoxide [4]. Frs 252-286 were combined $(493.0 \mathrm{mg}$ ) and crystallized in $\mathrm{MeOH}$ to give further $367.1 \mathrm{mg}$ of ergosterol 5,8-endoperoxide. Frs 287-299 were combined $\left(580.4 \mathrm{mg}\right.$ ) and crystallized in a mixture of $\mathrm{CHCl}_{3}-\mathrm{Me}_{2} \mathrm{CO}$ to give $78 \mathrm{mg}$ of 2a $[7,8]$, and the mother liquor was combined with frs 300-319 (837.2 mg) and precipitated in $\mathrm{Me}_{2} \mathrm{CO}$ to give $10.0 \mathrm{mg}$ of $\mathbf{1 b}$ [5]. The mother liquor ( $855 \mathrm{mg}$ ) was applied on a column chromatography of silica gal (30 g) and eluted with petrol- $\mathrm{CHCl}_{3}, \mathrm{CHCl}_{3}, \mathrm{CHCl}_{3}-\mathrm{Me}_{2} \mathrm{CO}$, and $\mathrm{MeOH}$, wherein $100 \mathrm{~mL}$ fractions were collected as follows: Sfrs 1-11 (petrol- $\mathrm{CHCl}_{3}, 1: 1$ ), $12-28$ (petrol- $\mathrm{CHCl}_{3}, 3: 7$ ), $29-86$ (petrol- $\mathrm{CHCl}_{3}$, 1:9), 87-126 $\left(\mathrm{CHCl}_{3}\right), 127-135\left(\mathrm{CHCl}_{3}-\mathrm{Me}_{2} \mathrm{CO}, 9: 1\right), 136-138\left(\mathrm{Me}_{2} \mathrm{CO}\right)$. Sfrs 100-126 were combined $\left(71.3 \mathrm{mg}\right.$ ) and purified by TLC (Silica gel $\mathrm{G}_{254}, \mathrm{CHCl}_{3}: \mathrm{Me}_{2} \mathrm{CO}: \mathrm{HCO}_{2} \mathrm{H}, 9: 1: 0.01$ ) to give further $10.0 \mathrm{mg}$ of $\mathbf{1 b}$. Sfrs 127 (48 mg) was crystallized in a mixture of $\mathrm{CHCl}_{3}-\mathrm{Me}_{2} \mathrm{CO}$ to give further $30.0 \mathrm{mg}$ of $\mathbf{2 a}$. Frs 343-366 were combined (1.46 g) and crystallized in $\mathrm{MeOH}$ to give $98.3 \mathrm{mg}$ of 4 , and the mother liquor was combined with frs 367-386 (1.77 g) and recrystallized in $\mathrm{MeOH}$ to give further $8.0 \mathrm{mg}$ of 1a [5]. The mother liquor of the combined frs 343-386 (1.36 g) was applied on a column chromatography of silica gel $(40 \mathrm{~g})$, and eluted with petrol- $\mathrm{CHCl}_{3}, \mathrm{CHCl}_{3}, \mathrm{CHCl}_{3}-\mathrm{Me}_{2} \mathrm{CO}$ and $\mathrm{Me}_{2} \mathrm{CO}$, wherein $100 \mathrm{~mL}$ fractions were collected as follows, Sfrs 1-50 (petrol- $\left.\mathrm{CHCl}_{3}, 1: 1\right), 51-88$ (petrol- $\left.\mathrm{CHCl}_{3}, 3: 7\right), 89-110$ (petrol- $\left.\mathrm{CHCl}_{3} ; 1: 9\right), 111-139\left(\mathrm{CHCl}_{3}\right), 140-197\left(\mathrm{CHCl}_{3}-\mathrm{Me}_{2} \mathrm{CO}, 9: 1\right), 198-201\left(\mathrm{CHCl}_{3}-\mathrm{Me}_{2} \mathrm{CO}, 7: 3\right)$, 202-215 ( $\left.\mathrm{Me}_{2} \mathrm{CO}\right)$. Sfrs 140-143 were combined (361.0 mg) and applied on a Sephadex LH-20 column $(10 \mathrm{~g})$, and eluted with $\mathrm{MeOH}$ to give $12.0 \mathrm{mg}$ of $\mathbf{1 a}$ and $10.1 \mathrm{mg}$ of 9 [3]. Sfrs 147-151 were combined $(221.0 \mathrm{mg})$ and applied on a Sephadex LH-20 column $(10 \mathrm{~g})$ and eluted with $\mathrm{MeOH}$ to give $10.0 \mathrm{mg}$ of a mixture of $\mathbf{2} \mathbf{b}$ (major component) [6] and $\mathbf{3 b}$. Sfrs 189-201 were combined (72.3 $\mathrm{mg}$ ) and purified by TLC (Silica gel $\mathrm{G}_{254}, \mathrm{CHCl}_{3}: \mathrm{MeOH}: \mathrm{HCO}_{2} \mathrm{H}, 95: 5: 0.1$ ) to give $7.1 \mathrm{mg}$ of 3a [9]. Frs 387-444 were combined $(2.73 \mathrm{~g})$ and applied on a column of Sephadex LH-20 $(20 \mathrm{~g})$ and eluted with MeOH, wherein $20 \mathrm{~mL}$ of 30 fractions were collected. Sfrs $11-30$ were combined $(472.3 \mathrm{mg})$ and crystallized in $\mathrm{Me}_{2} \mathrm{CO}$ to give further $19 \mathrm{mg}$ of 9 . The mother liquor was applied on a Sephadex LH-20 column $(20 \mathrm{~g})$ and eluted with a 1:1 mixture of $\mathrm{MeOH}-\mathrm{CHCl}_{3}$ to give $15 \mathrm{mg}$ of 7 [11]. Frs 517-529 were combined (1.40 g) and crystallized in $\mathrm{MeOH}$ to give $26.6 \mathrm{mg}$ of $1 \mathrm{e}$ [5], and the mother liquor was combined with frs $445-516$ (6.90 g) and applied on a column of Sephadex LH-20 column ( $30 \mathrm{~g})$ and eluted with $\mathrm{MeOH}$, wherein $20 \mathrm{~mL}$ fractions were collected. Sfrs $21-30$ were combined $(106.2 \mathrm{mg})$ and purified by TLC (Silica gel $\mathrm{G}_{254}, \mathrm{CHCl}_{3}: \mathrm{MeOH}: \mathrm{HCO}_{2} \mathrm{H}, 9: 1: 0.01$ ) to give $10 \mathrm{mg}$ of $3 \mathbf{a}[9,10]$ and $12 \mathrm{mg}$ of 6 . Sfrs 31-60 were combined $(5.90 \mathrm{~g})$ and applied on a column chromatography of silica gal (110 g) and eluted with petrol- $\mathrm{CHCl}_{3}, \mathrm{CHCl}_{3}, \mathrm{CHCl}_{3}-\mathrm{Me}_{2} \mathrm{CO}$ and $\mathrm{Me}_{2} \mathrm{CO}$, wherein $100 \mathrm{~mL}$ fractions were collected as follows, Sfrs 1-26 (petrol- $\mathrm{CHCl}_{3}, 1: 1$ ), 27-56 (petrol- $\mathrm{CHCl}_{3}, 3: 7$ ), 57-98 (petrol- $\mathrm{CHCl}_{3}, 1: 9$ ), 99-200 $\left(\mathrm{CHCl}_{3}\right), 201-297\left(\mathrm{CHCl}_{3}-\mathrm{Me}_{2} \mathrm{CO}, 9: 1\right), 298-320\left(\mathrm{CHCl}_{3}-\mathrm{Me}_{2} \mathrm{CO}, 7: 3\right), 321-332\left(\mathrm{CHCl}_{3}-\mathrm{Me}_{2} \mathrm{CO}, 1: 9\right)$, 333-358 ( $\mathrm{Me}_{2} \mathrm{CO}$ ). Sfrs 156-184 were combined (112.0 mg) and crystallized in $\mathrm{Me}_{2} \mathrm{CO}$ to give further $26.1 \mathrm{mg}$ of 9 . Sfrs $252-294$ were combined $(464.9 \mathrm{mg}$ ) and applied on a Sephadex LH-20 column ( $20 \mathrm{~g}$ ) and eluted with $\mathrm{MeOH}$ to give $23.0 \mathrm{mg}$ of 1c. Sfrs 295-344 were combined (3.0 g), applied on a Sephadex LH-20 column $(20 \mathrm{~g})$ and eluted with a 1:1 mixture of $\mathrm{MeOH}-\mathrm{CHCl}_{3}$, wherein $20 \mathrm{~mL}$ fractions were collected. Sfrs 31-72 were combined $\left(262.9 \mathrm{mg}\right.$ ) and purified by TLC (Silica gel $\mathrm{G}_{254}$, $\left.\mathrm{CHCl}_{3}: \mathrm{MeOH}: \mathrm{HCO}_{2} \mathrm{H}, 9: 1: 0.01\right)$ to give $12.1 \mathrm{mg}$ 1d [6]. Sfrs 73-96 were combined (90.6 mg) and purified by TLC (Silica gel $\mathrm{G}_{254}, \mathrm{CHCl}_{3}: \mathrm{MeOH}: \mathrm{HCO}_{2} \mathrm{H}, 9: 1: 0.01$ ) to give $10.6 \mathrm{mg}$ of $2 \mathrm{c}$ [9]. Sfrs 97-115 were combined $(644.8 \mathrm{mg}$ ) and precipitated in $\mathrm{MeOH}$ to give $12 \mathrm{mg}$ of a mixture of $\mathbf{2 b}$ and $\mathbf{3 b}$, and the mother liquor was dried $(619.7 \mathrm{mg})$ and applied on a Sephadex LH-20 column (10 g) and eluted with a 1:1 mixture of $\mathrm{CHCl}_{3}: \mathrm{MeOH}$, wherein 70 sub-fractions ( $2 \mathrm{~mL}$ each) were collected. Sfrs $25-32$ were 
combined (40.8 mg) and precipitated in $\mathrm{MeOH}$ to give $10 \mathrm{mg}$ of 1e [5]. Sfrs 33-45 were combined (70.1 mg) and purified by TLC (Silica gel $\mathrm{G}_{254}, \mathrm{CHCl}_{3}: \mathrm{MeOH}: \mathrm{HCO}_{2} \mathrm{H}, 9: 1: 0.01$ ) to give $6 \mathrm{mg}$ of 5 . Sfrs 46-56 were combined $(65.3 \mathrm{mg}$ ) and precipitated in $\mathrm{MeOH}$ to give further $7 \mathrm{mg}$ of 5 .

\subsubsection{1-Hydroxy-12-methoxycitromycin (1c)}

White solid, $\mathrm{mp} 232-233^{\circ} \mathrm{C}\left(\mathrm{CHCl}_{3} / \mathrm{MeOH}\right)$; IR (KBr) $v_{\max } 3420$ (br), 2921, 1662, 1627, 1594, 1555, 1517, 1453, $1270 \mathrm{~cm}^{-1}$; For ${ }^{1} \mathrm{H}$ and ${ }^{13} \mathrm{C}$ spectroscopic data (DMSO- $d_{6}, 500.13$ and $125.4 \mathrm{MHz}$ ), see Table 1; (+)-HRESIMS $m / z 277.0715$ [M + H] $]^{+}$(calculated for $\mathrm{C}_{14} \mathrm{H}_{13} \mathrm{O}_{6}, 277.0712$ ).

3.3.2. Erubescenschromone A [(3S)-6,7-Dihydroxy-5'-methyl-3' $H, 4 H$-spiro[chromene-3, $2^{\prime}$-furan]-3', 4-dione (4)]

White crystal, $\mathrm{mp} 150-152{ }^{\circ} \mathrm{C}\left(\mathrm{CHCl}_{3} / \mathrm{MeOH}\right) ;[\alpha]_{\mathrm{D}}^{23}-40.0\left(c 0.05, \mathrm{CDCl}_{3}\right) ; \mathrm{IR}(\mathrm{KBr}) v_{\max } 3491$, $3376,3108,2969,1679,1661,1648,1578,1523,1479,1276 \mathrm{~cm}^{-1}$; For ${ }^{1} \mathrm{H}$ and ${ }^{13} \mathrm{C}$ spectroscopic data (DMSO- $d_{6}, 500.13$ and $125.4 \mathrm{MHz}$ ), see Table 3; (+)-HRESIMS $m / z 263.0596[\mathrm{M}+\mathrm{H}]^{+}$(calculated for $\left.\mathrm{C}_{13} \mathrm{H}_{11} \mathrm{O}_{6}, 263.0556\right)$.

\subsubsection{7-Hydroxy-6-methoxy-4-oxo-3-[(1E)-3-oxobut-1-en-1-yl]-4H-chromene-5-carboxylic Acid (5)}

White crystal, mp $276-277^{\circ} \mathrm{C}\left(\mathrm{CHCl}_{3} / \mathrm{MeOH}\right)$; IR (KBr) $v_{\max } 3446,2922,1719,1646,1618,1560$, 1541, 1521, $1276 \mathrm{~cm}^{-1}$; For ${ }^{1} \mathrm{H}$ and ${ }^{13} \mathrm{C}$ spectroscopic data (DMSO, 500.13 and $125.4 \mathrm{MHz}$ ), see Table 4; (+)-HRESIMS $m / z 305.0667[\mathrm{M}+\mathrm{H}]^{+}$(calculated for $\mathrm{C}_{15} \mathrm{H}_{13} \mathrm{O}_{7}, 305.0661$ ).

\subsubsection{Erubescenschromone B (6)}

Yellowish oil; $[\alpha]_{\mathrm{D}}^{23}-150.0$ (c 0.04, MeOH); IR (KBr) $\nu_{\max } 3443$ (br), 2922, 1731, 1715, 1697, 1648, $1634,1556,1540,1506,1261 \mathrm{~cm}^{-1}$; For ${ }^{1} \mathrm{H}$ and ${ }^{13} \mathrm{C}$ spectroscopic data (DMSO- $d_{6}, 500.13$ and $125.4 \mathrm{MHz}$ ), see Table 5; (+)-HRESIMS $m / z 509.1085[\mathrm{M}+\mathrm{H}]^{+}$(calculated for $\mathrm{C}_{26} \mathrm{H}_{21} \mathrm{O}_{11}, 509.1084$ ).

\subsubsection{SPF-3059-30 (7)}

Yellowish oil; IR (KBr) $v_{\max } 3491,3376,3108,2969,1679,1661,1648,1578,1523,1479,1276 \mathrm{~cm}^{-1}$; For ${ }^{1} \mathrm{H}$ and ${ }^{13} \mathrm{C}$ spectroscopic data (DMSO- $d_{6}, 500.13$ and $125.4 \mathrm{MHz}$ ), see Table 6; (+)-HRESIMS $\mathrm{m} / z$ $491.0974[\mathrm{M}+\mathrm{H}]^{+}$(calculated for $\mathrm{C}_{26} \mathrm{H}_{19} \mathrm{O}_{10}, 491.0978$ ).

\subsection{Electronic Circular Dichroism (ECD)}

\section{Electronic Circular Dichroism (ECD) of $\mathbf{3 a}$ and $\mathbf{6}$}

The ECD spectra of $\mathbf{3 a}$ and $\mathbf{6}(1.5 \mathrm{mM}$ in methanol) were obtained in a Jasco J-815 CD spectropolarimeter (Jasco, Mary's Court, Easton, MD, USA) with a $0.01 \mathrm{~mm}$ cell (40 accumulations for 3a). The dihedral driver and MMFF95 minimizations were done in Chem3D Ultra (Perkin-Elmer Inc., Waltham, MA, USA). All DFT minimizations with model chemistries APFD/6-31G and APFD/6-311+G(2d,p) [25] as well as ECD spectral calculations (TD-APFD) were performed with Gaussian 16W (Gaussian Inc., Wallingford, CT, USA) using an IEFPCM solvation model for methanol. The simulated spectral lines for $\mathbf{3 a}$ (Figure 3) and $\mathbf{6}$ (Figure 8) were obtained by summation of Gaussian curves, as recommended in Reference [26]. A line broadening of $0.3 \mathrm{eV}$ was applied to all transitions to generate the calculated line.

\subsection{X-ray Crystal Structures}

\subsubsection{X-ray Crystal Structure of 4}

A single crystal of 4 was mounted on a cryoloop using paratone. X-ray diffraction data were collected at $290 \mathrm{~K}$ with a Gemini PX Ultra equipped with $\mathrm{CuK}_{\alpha}$ radiation $(\lambda=1.54184 \AA)$. The crystal was monoclinic, space group $P 2_{1} / n$, cell volume $1245.43(7) \AA^{3}$ and unit cell dimensions $a=12.3445(4)$ 
$\AA, b=7.8088(3) \AA$ and $c=12.9397(5) \AA$ and angle $\beta=93.165(3)^{\circ}$ (uncertainties in parentheses). There are two molecules in the asymmetric unit, one Erubescenschromone A molecule and one water molecule, and the calculated crystal density is $1.495 \mathrm{~g} / \mathrm{cm}^{-3}$. The structure was solved by direct methods using SHELXS-97 and refined with SHELXL-97 [27]. Carbon and oxygen atoms were refined anisotropically. Hydrogen atoms were directly found from difference Fourier maps and were refined freely with isotropic displacement parameters. The refinement converged to $\mathrm{R}$ (all data) $=6.32 \%$ and $\mathrm{w} R 2$ (all data) $=11.26 \%$.

Full details of the data collection and refinement and tables of atomic coordinates, bond lengths and angles, and torsion angles have been deposited with the Cambridge Crystallographic Data Centre (CCDC 1856735).

\subsubsection{X-ray Crystal Structure of 5}

A single crystal of 5 was mounted on a cryoloop using paratone. X-ray diffraction data were collected at $290 \mathrm{~K}$ with a Gemini PX Ultra equipped with $\mathrm{CuK}_{\alpha}$ radiation $(\lambda=1.54184 \AA)$. The crystal was monoclinic, space group $P 2_{1} / c$, cell volume 1324.77(16) $\AA^{3}$ and unit cell dimensions $a=11.6888(8) \AA, b=7.7695(4) \AA$ and $c=14.9560(12) \AA$ and angle $\beta=102.748(7)^{\circ}$ (uncertainties in parentheses). The calculated crystal density was $1.525 \mathrm{~g} \cdot \mathrm{cm}^{-3}$. The structure was solved by direct methods using SHELXS-97 and refined with SHELXL-97 [27]. Carbon and oxygen atoms were refined anisotropically. Hydrogen atoms from one of the methyl groups were placed at their idealized positions using appropriate HFIX instructions in SHELXL and included in subsequent refinement cycles, all the others were directly found from difference Fourier maps and were refined freely with isotropic displacement parameters. The refinement converged to $\mathrm{R}$ (all data) $=12.24 \%$ and $\mathrm{wR} 2$ (all data) $=14.96 \%$.

Full details of the data collection and refinement and tables of atomic coordinates, bond lengths and angles, and torsion angles have been deposited with the Cambridge Crystallographic Data Centre (CCDC 1859409).

\subsection{Antibacterial Activity Bioassays}

\subsubsection{Bacterial Strains and Growth Conditions}

Gram-positive bacteria included Staphylococcus aureus ATCC 29213, Enterococcus faecium ATCC 19434, Enterococcus faecalis ATCC 29212, methicillin-resistant Staphylococcus aureus (MRSA) 66/1 isolated from public buses [28], and vancomycin-resistant enterococci (VRE) Enterococcus faecium 1/6/63 and Enterococcus faecalis B3/101 isolated from river water [29]. Gram-negative strains comprised Escherichia coli ATCC 25922, Pseudomonas aeruginosa ATCC 27853 and the clinical isolate SA/2, an extended-spectrum $\beta$-lactamase producer (ESBL). All strains were kept in Trypto-Casein Soy agar (TSA-Biokar Diagnostics, Allone, Beauvais, France) slants, at room temperature, in the dark. Before each assay, all strains were cultured in Mueller-Hinton agar (MH-Biokar Diagnostics, Allone, Beauvais, France) and incubated overnight at $37^{\circ} \mathrm{C}$. Stock solutions of the compounds were prepared in dimethyl sulfoxide (DMSO-Alfa Aesar, Kandel, Germany) and kept at $-20^{\circ} \mathrm{C}$. With the exception of $1 \mathbf{e}, 10 \mathrm{mg} / \mathrm{mL}$ stock solutions were prepared. Compound 1e was less soluble in DMSO than other compounds, so a $2 \mathrm{mg} / \mathrm{mL}$ stock solution was prepared. In the experiments, the final concentration of DMSO in the medium was below $1 \%$, as recommended by the Clinical and Laboratory Standards Institute [30].

\subsubsection{Antimicrobial Susceptibility Testing}

The antimicrobial activity of the compounds was screened using the Kirby-Bauer method, as recommended by the CLSI [31]: $6 \mathrm{~mm}$ blank paper discs (Liofilchem, Roseto degli Abruzzi TE, Italy) were impregnated with $15 \mu \mathrm{g}$ of each compound, and the blank paper discs impregnated with DMSO were used as negative control. MH inoculated plates were incubated for $18-20 \mathrm{~h}$ at $37^{\circ} \mathrm{C}$. The results were evaluated by measuring the inhibition halos. The minimal inhibitory concentration (MIC) was performed in accordance with the recommendations of the CLSI [32]. Two-fold serial dilutions of 
the compounds were prepared in cation-adjusted Mueller-Hinton broth (CAMHB-Sigma-Aldrich, St. Louis, MO, USA) within the concentration range $64-0.063 \mathrm{mg} / \mathrm{L}$, except for $1 \mathbf{e}$, for which the highest concentration tested was $32 \mathrm{mg} / \mathrm{L}$. Colony forming unit counts of the inoculum were conducted in order to determine the initial inoculum size (which should be approximately $5 \times 10^{5} \mathrm{CFU} / \mathrm{mL}$ ). The 96-well U-shaped untreated polystyrene microtiter plates were incubated for $16-20 \mathrm{~h}$ at $37^{\circ} \mathrm{C}$ and the MIC was determined as the lowest concentration of compound that prevented visible growth. The minimal bactericidal concentration (MBC) was determined by spreading $100 \mu \mathrm{L}$ of the content of the wells with no visible growth on the MH plates. The MBC was determined as the lowest concentration of compound that killed $99.9 \%$ of the initial inoculum after overnight incubation at $37^{\circ} \mathrm{C}$ [33]. These assays were conducted for reference and multidrug-resistant strains.

\subsubsection{Biofilm Formation Inhibition Assay}

The effect of all compounds on biofilm formation was evaluated using the crystal violet method, as follows: the highest concentration of the tested compound in the MIC assay was added to bacterial suspensions of $1 \times 10^{6} \mathrm{CFU} / \mathrm{mL}$ prepared in unsupplemented Tryptone Soy broth (TSB-Biokar Diagnostics, Allone, Beauvais, France) or TSB supplemented with 1\% $(p / v)$ glucose [D-(+)-Glucose anhydrous for molecular biology, PanReac AppliChem, Barcelona, Spain] for Gram-positive strains. When it was possible to determine a MIC, four concentrations of compound were tested, i.e., $2 \times$ MIC, MIC, $\frac{1}{2}$ MIC and $\frac{1}{4}$ MIC. A control with appropriate concentration of DMSO, as well as a negative control (TSB alone), was included. Sterile 96 -well flat-bottomed untreated polystyrene microtiter plates were used. After a $24 \mathrm{~h}$ incubation at $37^{\circ} \mathrm{C}$, the biofilms were heat-fixed for $1 \mathrm{~h}$ at $60^{\circ} \mathrm{C}$ and stained with $0.5 \%(v / v)$ crystal violet (Química Clínica Aplicada, Amposta, Spain) for $5 \mathrm{~min}$. The stain was solubilized with 33\% (v/v) acetic acid (Acetic acid 100\%, AppliChem, Darmstadt, Germany) and the biofilm biomass was quantified by measuring the absorbance of each sample at $570 \mathrm{~nm}$ in a microplate reader (Thermo Scientific Multiskan ${ }^{\circledR}$ EX, Thermo Fisher Scientific, Waltham, MA, USA) [20,34]. This assay was performed for reference strains.

\subsubsection{Antibiotic Synergy Testing}

The potential synergy between the compounds and clinically relevant antimicrobial drugs was screened using the Kirby-Bauer method, as previously described [35]. A set of antibiotic discs (Oxoid, Basingstoke, UK) to which the isolates were resistant was selected: cefotaxime (CTX, $30 \mu \mathrm{g})$ for E. coli $\mathrm{SA} / 2$, vancomycin (VAN, $30 \mu \mathrm{g}$ ) for E. faecalis B3/101 and E. faecium 1/6/63, and oxacillin (OXA, $1 \mu \mathrm{g}$ ) for $S$. aureus 66/1. Antibiotic discs impregnated with $15 \mu \mathrm{g}$ of each compound were placed on seeded MH plates. The controls used included antibiotic discs alone, blank paper discs impregnated with $15 \mu \mathrm{g}$ of each compound alone and blank discs impregnated with DMSO. Plates with CTX were incubated for 18-20 $\mathrm{h}$ and plates with VAN and OXA were incubated for $24 \mathrm{~h}$ at $37^{\circ} \mathrm{C}$ [30]. The potential synergy was considered when the inhibition halo of an antibiotic disc impregnated with the compound was greater than the inhibition halo of the antibiotic or compound-impregnated blank disc alone. The combined effect of the compounds and clinical relevant antimicrobial drugs was also evaluated by determining the antibiotic MIC in the presence of each compound. Briefly, when it was not possible to determine a MIC value for the test compound, the MIC of CTX (Duchefa Biochemie, Haarlem, The Netherlands), VAN (Oxoid, Basingstoke, UK), and OXA (Sigma-Aldrich, St. Louis, $\mathrm{MO}, \mathrm{USA}$ ) for the respective multidrug-resistant strain was determined in the presence of the highest concentration of each compound tested in previous assays. In the case of $\mathbf{1 e}$, the concentration used was $32 \mathrm{mg} / \mathrm{L}$ while it was $64 \mathrm{mg} / \mathrm{L}$ for the other compounds. The antibiotic tested was serially diluted whereas the concentration of each compound was kept fixed. Antibiotic MICs were determined as described above. For 7, it was possible to determine the MIC for E. faecalis B3/101 and E. faecium $1 / 6 / 63$, so the checkerboard method was used instead, as previously described [34]. The fractional inhibitory concentrations (FIC) were calculated as follows: FIC of compound = MIC of compound combined with antibiotic $/$ MIC compound alone, and FIC antibiotic = MIC of antibiotic combined with 
a compound/MIC of antibiotic alone. The FIC index (FICI) was calculated as the sum of each FIC and interpreted as follows: FICI $\leq 0.5$, 'synergy'; $0.5<$ FICI $\leq 4$, 'no interaction'; FICI $>4$, 'antagonism' [36].

\section{Conclusions}

Marine-derived fungi have proved to be important sources of bioactive secondary metabolites, many of which exhibit cytotoxic and antibiotic activities. One of the most studied marine-derived fungi is of the genus Penicillium. In the past ten years, the Penicillium species from the marine environment received more attention than other fungal genera since compounds isolated from members of the Penicillium genus accounted for more than $25 \%$ of compounds of marine fungal origin. Although polyketides are the major secondary metabolites isolated from marine-derived Penicillium species, other structural classes of secondary metabolites such as alkaloids, terpenoids, and sterols are also isolated. In this work, we have described isolation and structure elucidation of two common fungal sterol derivatives: $\beta$-sitostenone and ergosterol 5,8-endoperoxide, fifteen polyketides, five of which have not been previously described, and a macrocyclic ether containing 1,4-disubstituted phenyl and succinamide moiety called GKK1032B, from the culture of the fungus P. erubescens strain KUFA 0220, which was isolated from the marine sponge Neopetrosia sp., collected from the Gulf of Thailand. From the compounds evaluated for their antibacterial activity against Gram-positive and Gram-negative bacteria of reference strains and multidrug-resistant isolates, their capacity to inhibit biofilm formation and synergistic effect, only GKK1032B displayed significant activities in all assays. Although the rest of the compounds, including those which have not been previously described, did not show significant antibacterial activity, it does not mean that they are void of bioactivities. Therefore, it is necessary to test these compounds in other bioassay platforms to explore their potential. Finally, it is worth mentioning that this is the first report of the chemical study of the marine-derived P. erubescens.

Supplementary Materials: The following are available online at http://www.mdpi.com/1660-3397/16/8/ 289/s1, Figure S1: Structures of $\beta$-sitosteanone and ergosterol-5,8-endoperoxide, isolated from the marine sponge-associated fungus Penicillium reubescens KUFA0220, Figures S2-S50 and S52-S53: 1D and 2D NMR spectra of isolated compounds, Figure S51: Ortep view of GKK1032B (8).

Author Contributions: A.K., M.M.M.P. and J.A.P. conceived, designed the experimental and elaborated the manuscript; D.K. performed isolation, purification and structure elucidation of the compounds; T.D. collected, isolated, identified and cultured the fungus; L.G. performed X-ray analysis; J.A.P. performed calculations and measurement of ECD spectra. P.M.C. and J.F.S. performed and interpreted the results of antibacterial assays; N.S. assisted elaboration of the manuscript; M.L. provided HRMS; A.M.S.S. provided NMR spectra.

Funding: This research was funded by Fundação para a Ciências e Tecnologia (FCT) (grant number POCI-01-0145-FEDER-016790) and North Portugal Regional Operational Programme (NORTE 2020)(grant number NORTE-01-0145-FEDER-000035).

Acknowledgments: This work was partially supported through national funds provided by FCT/MCTESFoundation for Science and Technology from the Minister of Science, Technology and Higher Education (PIDDAC) and European Regional Development Fund (ERDF) through the COMPETE-Programa Operacional Factores de Competitividade (POFC) programme, under the project PTDC/MAR-BIO/4694/2014 (reference POCI-01-0145-FEDER-016790; Project 3599-Promover a Produção Científica e Desenvolvimento Tecnológico e a Constituição de Redes Temáticas (3599-PPCDT)) in the framework of the programme PT2020 as well as by the project INNOVMAR-Innovation and Sustainability in the Management and Exploitation of Marine Resources (reference NORTE-01-0145-FEDER-000035, within Research Line NOVELMAR), supported by North Portugal Regional Operational Programme (NORTE 2020), under the PORTUGAL 2020 Partnership Agreement, through the European Regional Development Fund (ERDF). Decha Kumla thanks the Alfabet Project of the Erasmus Mundus for a PhD's scholarship. We thank Júlia Bessa and Sara Cravo for technical support.

Conflicts of Interest: The authors declare no conflict of interest.

\section{References}

1. Visagle, C.M.; Houbraken, J.; Frisvad, J.C.; Hong, S.B.; Klaassen, C.H.W.; Perrone, G.; Seifert, K.A.; Vatga, J.; Yaguchi, T.; Samson, R.A. Identification and nomenclature of the genus Penicillium. Sud. Mycol. 2014, 78, 343-371. [CrossRef] [PubMed] 
2. Ma, H.-G.; Liu, Q.; Zhu, G.-L.; Liu, H.-S.; Zhu, W.-M. Marine Natural Products sources from marine-derived Penicillium fungi. J. Asian Nat. Prod. Res. 2016, 18, 92-115. [CrossRef] [PubMed]

3. Kumla, D.; Aung, T.S.; Buttachon, S.; Dethoup, T.; Gales, L.; Pereira, J.A.; Inácio, A.; Costa, P.M.; Lee, M.; Sekeroglu, N.; et al. A New Dihydrochromone Dimer and Other Secondary Metabolites from Cultures of the Marine Sponge-Associated Fungi Neosartorya fennelliae KUFA 0811 and Neosartorya tsunodae KUFC 9213. Mar. Drugs 2017, 15, 375. [CrossRef] [PubMed]

4. May Zin, W.W.; Buttachon, S.; Dethoup, T.; Pereira, J.A.; Gales, L.; Inácio, A.; Costa, P.M.; Lee, M.; Sekeroglu, N.; Silva, A.M.S.; et al. Antibacterial and antibiofilm activities of the metabolites isolated from the culture of the mangrove-derived endophytic fungus Eurotium chevalieri KUFA0006. Phytochemistry 2017, 141, 86-97. [CrossRef] [PubMed]

5. Capon, R.J.; Stewart, M.; Ratnayake, R.; Lacey, E.; Gill, J.H. Citromycetins and Bilains A-C: Newaromatic polyketides and diketopiperazines from Australian Marine-Derived and Terrestrial Penicillium spp. J. Nat Prod. 2007, 70, 1746-1752. [CrossRef] [PubMed]

6. Yuan, C.; Wang, H.-Y.; Wu, C.-S.; Jiao, Y.; Li, M.; Wang, Y.-Y.; Wang, S.-Q.; Zhao, Z.-T.; Lou, H.-X. Austdiol, fulvic acid and citromycetin derivative from an endolichenic fungus, Myxotrichum sp. Phytochem. Lett. 2013, 6, 662-666. [CrossRef]

7. Fujita, K.-I.; Nagamine, Y.; Ping, X.; Taniguchi, M. Mode of Action of anhydrofulvic acid against Candida utilis ATCC 42402 under acid condition. J. Antibiot. 1999, 52, 628-634. [CrossRef] [PubMed]

8. Lee, D.-S.; Jang, J.-H.; Ko, W.; Kim, K.-S.; Sohn, J.H.; Kang, M.-S.; Ahn, J.S.; Kim, Y.-C.; On, H. PTP1B inhibitory and anti-inflamatory effects of secondary metabolites isolated from the marine-derived fungus Penicillium sp. JF-55. Mar. Drugs 2013, 11, 1409-1429. [CrossRef] [PubMed]

9. Cheng, X.; Yu, L.; Wang, Q.; Ding, W.; Chen, Z.; Ma, Z. New brefeldins and penialidins from marine fungus Penicillium janthinellum DT-F29. Nat. Prod. Res. 2018, 32, 282-286. [CrossRef] [PubMed]

10. Jouda, J.B.; Kusari, S.; Lamshoft, M.; Moufo Taontsi, F.; Douala Meli, C.; Wandji, J.; Spitteller, M. Penialidins A-C with strong bacterial acivity from Penicillium sp., an endophytic fungus harboring leaves of Garcinia nobilis. Fitoterapia 2014, 98, 209-214. [CrossRef] [PubMed]

11. Kimura, T.; Kikuchi, K.; Kumagai, K.; Hosotani, N.; Kishino, A. Nerve Regeneration Promoters Containing Semaphorin Inhibitor as the Active Ingredient. European Patent EP 1306093 B1. Date of Publication and Mention of the Grant of the Patent 03.10. 2007. Bulletin 2007/40. Available online: https://data.epo.org/ publication-server/rest/v1.0/publication-dates/20071003/patents/EP1306093NWB1/document.html (accessed on 7 July 2018).

12. Song, T.; Chen, M.; Chai, W.; Zhang, Z.; Lian, X.-Y. New bioactive pyrrospirones C-I from a marine-derived fungus Penicillium sp. ZZ380. Tetrahedron 2018, 74, 884-891. [CrossRef]

13. Rukachaisirikul, V.; Satpradit, S.; Klaiklay, S.; Phongpaichit, S.; Borwornwiriyapan, K.; Sakayaroj, J. Polyketide anthraquinone, diphenyl ether, and xanthone derivatives from the soil fungus Penicillium sp. PSU-RSPG99. Tetrahedron 2014, 70, 5148-5152. [CrossRef]

14. Pastre, R.; Marinho, A.M.R.; Rodrigues-Filho, E.; Souza, A.Q.L.; Pereira, J.O. Diversity of polyketides produced by Penicillium species isolated from Melia azedarach and Murraya paniculata. Quim. Nova 2007, 30, 1867-1871. [CrossRef]

15. Noinart, J.; Buttachon, S.; Dethoup, T.; Gales, L.; Pereira, J.A.; Urbatzka, R.; Freitas, S.; Lee, M.; Silva, A.M.S.; Pinto, M.M.M.; et al. A new ergosterol analog, a new bis-anthraquinone and anti-obesity activity of anthraquinones from the marine sponge-associated fungus Talaromyces stipitatus KUFA 0207. Mar. Drugs 2017, 15, 139. [CrossRef] [PubMed]

16. Arai, K.; Miyajima, H.; Mushiroda, T.; Yamamoto, Y. Metabolites of Penicillium italicum Wehmer. Isolation and structures of new metabolites including naturally occurring 4-ylidene-acyltetronic acids, italicinic acid and italicic acid. Chem. Pharm. Bull. 1989, 37, 3229-3235. [CrossRef]

17. Lu, K.; Zhang, Y.; Li, L.; Wang, X.; Ding, G. Chaetochromones A and B, two new polyketides from the fungus Chaetomium indicum (CBS.860.68). Molecules 2013, 18, 10944-10952. [CrossRef] [PubMed]

18. Kumagai, K.; Hosotani, N.; Kikuchi, K.; Kimuran, T.; Saji, I. Xanthofulvin, a novel semaphorin inhibitor produced by a strain of Penicillium. J. Antibiot. 2003, 56, 610-616. [CrossRef] [PubMed]

19. Stepanović, S.; Vuković, D.; Dakic, I.; Savić, B.; Švabic-Vlahović, M. A modified -plate test for quantification of staphylococcal biofilm formation. J. Microbiol. Methods 2000, 40, 175-179. [CrossRef] 
20. Stepanović, S.; Vuković, D.; Hola, V.; Di Bonaventura, G.; Djukić, S.; Ćirković, I.; Ruzicka, F. Quantification of biofilm in microtiter plates: Overview of testing conditions and practical recommendations for assessment of biofilm production by staphylococci. Apmis 2007, 115, 891-899. [CrossRef] [PubMed]

21. Tacconelli, E.; Carrara, E.; Savoldi, A.; Harbarth, S.; Mendelson, M.; Monnet, D.L.; Pulcini, C.; Kahlmeter, G.; Kluytmans, J.; Carmeli, Y.; et al. Discovery, research, and development of new antibiotics: The WHO priority list of antibiotic-resistant bacteria and tuberculosis. Lancet Infect. Dis. 2017, 18, 318-327. [CrossRef]

22. Murray, M.G.; Thompson, W.F. Rapid isolation of high molecular weight plant DNA. Nucleic Acids Res. 1980, 8, 4321-4325. [CrossRef] [PubMed]

23. White, T.J.; Bruns, T.; Lee, S.; Taylor, J. Amplification and direct sequencing of fungal ribosomal RNA genes for phylogenetics. In PCR Protocols: A Guide to Methods and Applications; Innis, M.A., Gelfand, D.H., Sninsky, J.J., White, T.J., Eds.; Academic Press: New York, NY, USA, 1990; pp. 315-322.

24. Sanger, F.; Nicklen, S.; Coulson, A.R. DNA sequencing with chain-terminating inhibitors. Proc. Natl. Acad. Sci. USA 1977, 72, 5463-5467. [CrossRef]

25. Austin, A.; Petersson, G.A.; Frisch, M.J.; Dobek, F.J.; Scalmani, G.; Throssel, K. A density functional with Spherical atom dispersion terms. J. Chem. Theory Comput. 2012, 8, 4989-5007. [CrossRef] [PubMed]

26. Stephens, P.J.; Harada, N. ECD Cotton effect approximated by the Gaussian curve and other methods. Chirality 2010, 22, 229-233. [CrossRef] [PubMed]

27. Sheldrick, G.M. A short story of SHELX. Acta Cryst. 2008, A64, 112-122. [CrossRef] [PubMed]

28. Simões, R.R.; Aires-de-Sousa, M.; Conceicao, T.; Antunes, F.; da Costa, P.M.; de Lencastre, H. High prevalence of EMRSA-15 in Portuguese public buses: A worrisome finding. PLoS ONE 2011, 6, e17630. [CrossRef] [PubMed]

29. Bessa, L.J.; Barbosa-Vasconcelos, A.; Mendes, A.; Vaz-Pires, P.; Martins da Costa, P. High prevalence of multidrug-resistant Escherichia coli and Enterococcus spp. in river water, upstream and downstream of a wastewater treatment plant. J. Water Health 2014, 12, 426-435. [CrossRef] [PubMed]

30. Clinical and Laboratory Standards Institute (CLSI). Performance Standards for Antimicrobial Susceptibility Testing, 27th ed.; CLSI Supplement M100; Clinical and Laboratory Standards Institute: Wayne, PA, USA, 2017.

31. Clinical and Laboratory Standards Institute (CLSI). Performance Standards for Antimicrobial Disk Susceptibility Tests; Approved Standard-11th ed., CLSI Document M02-A11; Clinical and Laboratory Standards Institute: Wayne, PA, USA, 2012.

32. Clinical and Laboratory Standards Institute (CLSI). Methods for Dilution Antimicrobial Susceptibility Tests for Bacteria That Grow Aerobically; Approved Standard-10th ed., CLSI Document M07-A10; Clinical and Laboratory Standards Institute: Wayne, PA, USA, 2015.

33. Clinical and Laboratory Standards Institute (CLSI). Methods for Determining Bactericidal Activity of Antimicrobial Agents; Approved Guideline; Clinical and Laboratory Standards Institute: Wayne, PA, USA, 1999.

34. Gomes, N.M.; Bessa, L.J.; Buttachon, S.; Costa, P.M.; Buaruang, J.; Dethoup, T.; Silva, A.M.S.; Kijjoa, A. Antibacterial and antibiofilm activities of tryptoquivalines and meroditerpenes isolated from the marine-derived fungi Neosartorya paulistensis, N. laciniosa, N. tsunodae, and the soil fungi N. fischeri and N. siamensis. Mar. Drugs 2014, 12, 822-839. [CrossRef] [PubMed]

35. Buttachon, S.; Ramos, A.A.; Inácio, Â.; Dethoup, T.; Gales, L.; Lee, M.; Costa, P.M.; Silva, A.M.S.; Sekeroglu, N.; Rocha, E.; et al. Bis-indolyl benzenoids, hydroxypyrrolidine derivatives and other constituents from cultures of the marine sponge-associated fungus Aspergillus candidus KUFA0062. Mar. Drugs 2018, 16, 119. [CrossRef] [PubMed]

36. Odds, F.C. Synergy, antagonism, and what the chequerboard puts between them. J. Antimicrob. Chemother. 2003, 52. [CrossRef] [PubMed]

(C) 2018 by the authors. Licensee MDPI, Basel, Switzerland. This article is an open access article distributed under the terms and conditions of the Creative Commons Attribution (CC BY) license (http:/ / creativecommons.org/licenses/by/4.0/). 